\title{
2. BIOSTRATIGRAPHIC AND MAGNETOSTRATIGRAPHIC SYNTHESIS OF THE CELEBES AND SULU SEAS, LEG 1241
}

\author{
Jih-Ping Shyu, ${ }^{2}$ Dean Merrill, ${ }^{2}$ Vindell Hsu, ${ }^{3}$ Michael A. Kaminski, ${ }^{4}$ Carla M. Müller, ${ }^{5}$ Alexandra J. Nederbragt, ${ }^{6}$ \\ Reed P. Scherer, ${ }^{7}$ and Hidetoshi Shibuya ${ }^{8}$
}

\begin{abstract}
During ODP Leg 124, late middle Eocene to Quaternary sediment sequences were recovered from 13 holes drilled at five sites in the Celebes and Sulu basins. Paleomagnetic measurements and biostratigraphic studies using calcareous nannofossils, planktonic and benthic foraminifers, radiolarians, and diatoms were completed and summarized here. Two Neogene sediment sections recovered in the Sulu Basin yielded excellent core recoveries and magnetic reversal records, allowing direct magnetobiostratigraphic correlations for the Pliocene and Quaternary at Site 768 and for the middle Miocene to Quaternary at Site 769. The interpolated ages of biohorizons are not consistent between sites and only a few of them are in good agreement with previous calibrations. The differences may be the results of redeposition by turbidity currents and selective dissolution of key fossils.
\end{abstract}

\section{INTRODUCTION}

During Leg 124, 13 holes were dril':d at five sites in the Celebes and Sulu Seas (Fig. 1, Table 1). Sediment sequences recovered at these sites range in age from late middle Eocene to Quaternary in the Celebes Basin and from late early Miocene to Quaternary in the Sulu Basin. Shipboard and shore-based studies on biostratigraphy and magnetostratigraphy were completed (Kaminski and Huang, this volume; Merrill, Hsu, and Shibuya, this volume; Nederbragt, this volume; Scherer and Lazarus, this volume; Shyu and Müller, this volume; Rangin, Silver, von Breymann, et al., 1990), and the results are synthesized and evaluated in this paper.

Sediment cores recovered by APC (advanced piston core) coring at Sites 768 and 769 yielded almost complete recoveries and fairly reliable magnetic reversal records down to about 9 $\mathrm{Ma}$, providing the opportunity for direct correlation of the late Miocene to Quaternary magnetostratigraphy and biostratigraphy in the low-latitude Sulu Basin to evaluate the reliability of biohorizons. Because of dissolution and redeposition, most fossil groups recovered in Leg 124 samples, except the calcareous nannofossils, do not provide sufficient data to define clear biostratigraphic zonations. Numerical ages of biohorizons recognized at Sites 768 and 769 are interpolated from the age vs. depth plots. The interpolated ages are not consistent between sites, and most of them also differ from calibrations made in previous studies. Magnetic polarity changes could not be recognized in sediments older than late Miocene at Sites

\footnotetext{
${ }^{1}$ Rangin, C., Silver, E. A., von Breymann, M. T., et al., 1991. Proc. ODP. Sci. Results, 124: College Station, TX (Ocean Drilling Program).

2 Department of Oceanography, Texas A\&M University, College Station, Texas 77843, U.S.A.

${ }^{3}$ Department of Geology and Geophysics, Louisiana State University, Baton Rouge, Louisiana 70803-4101, U.S.A.

${ }^{4}$ Department of Paleontology, GEOMAR, Wischhofstr. 1-3, D-2300 Kiel 14, Federal Republic of Germany.

${ }_{5}$ Geologisch-Plaontologisches Institut, Universiät Frankfurt, SenckenbergAnlage 32- 34, D-6000 Frankfurt/Main, Federal Republic of Germany.

${ }^{6}$ Instituut voor Aardwetenschappen, Vrije Universiteit, P.O.B. 7161, 1007 MC Amsterdam, the Netherlands.

${ }^{7}$ Department of Geology and Minerology, The Ohio State University, Columbus, Ohio 43210-2721, U.S.A.

${ }^{8}$ Department of Earth Science, College of Integrated Art and Science, University of Osaka Prefecture, Sakai 591, Japan.
}

768 and 769 and other sites of this leg with only two exceptions; consequently, age assignments are based entirely on biostratigraphic horizons or events.

\section{MAGNETOSTRATIGRAPHY}

During Leg 124, the magnetic polarity sequence of the sediment column was determined by measuring the archived halves of all sections of APC cores in the pass-through cryogenic magnetometer at $10-\mathrm{cm}$ intervals at both natural remnant magnetization (NRM) and at least one step of demagnetization level. The selected demagnetization level for a core was determined by progressive demagnetization of one fulllength section at $0,5,10$, and $20 \mathrm{mT}$. For Site 768 cores, about $200 \mathrm{~m}$ of RCB (Rotary Core Barrel) cores were also measured in the pass-through magnetometer because individual pieces of sediment are longer than the sensor region $(25 \mathrm{~cm})$ of the magnetometer. Discrete samples were taken from APC cores and the underlying XCB (extended core barrel) and RCB sediment cores by pushing a $6-\mathrm{cm}^{3}$ plastic box into the undisturbed sediments. These samples were measured with shipboard and shore-based cryogenic magnetometers.

At Sites 767,768 , and 769 , both inclination and declination were measured. As all sites are located at very low latitudes, the inclinations are very low (either positive or negative) throughout the sediment column, and hence the identification of reversals were based mainly on declination swings of $180^{\circ}$. At reversal boundaries, the measurement was taken every 0.5 $\mathrm{cm}$ at 10,15 , and $20 \mathrm{mT}$ of demagnetization level, and deconvolution was performed during shore-based studies to recover the high-frequency changes of magnetization. All identified reversals are correlated with the geomagnetic reversal time scale of Berggren et al. (1985a, b, c; Fig. 2), using the geochronologic time scale framework established by biostratigraphic age assignments. The age of the Reunion Subchron is taken from Harland et al. (1982). The adopted ages of all recorded reversals are listed in Table 2.

\section{BIOSTRATIGRAPHY}

\section{Calcareous Nannofossils}

The Calcareous nannofossil biostratigraphic framework of Leg 124 is based mainly on the Standard Zonation of Martini (1971; Martini and Müller, 1986). Biohorizons other than the 


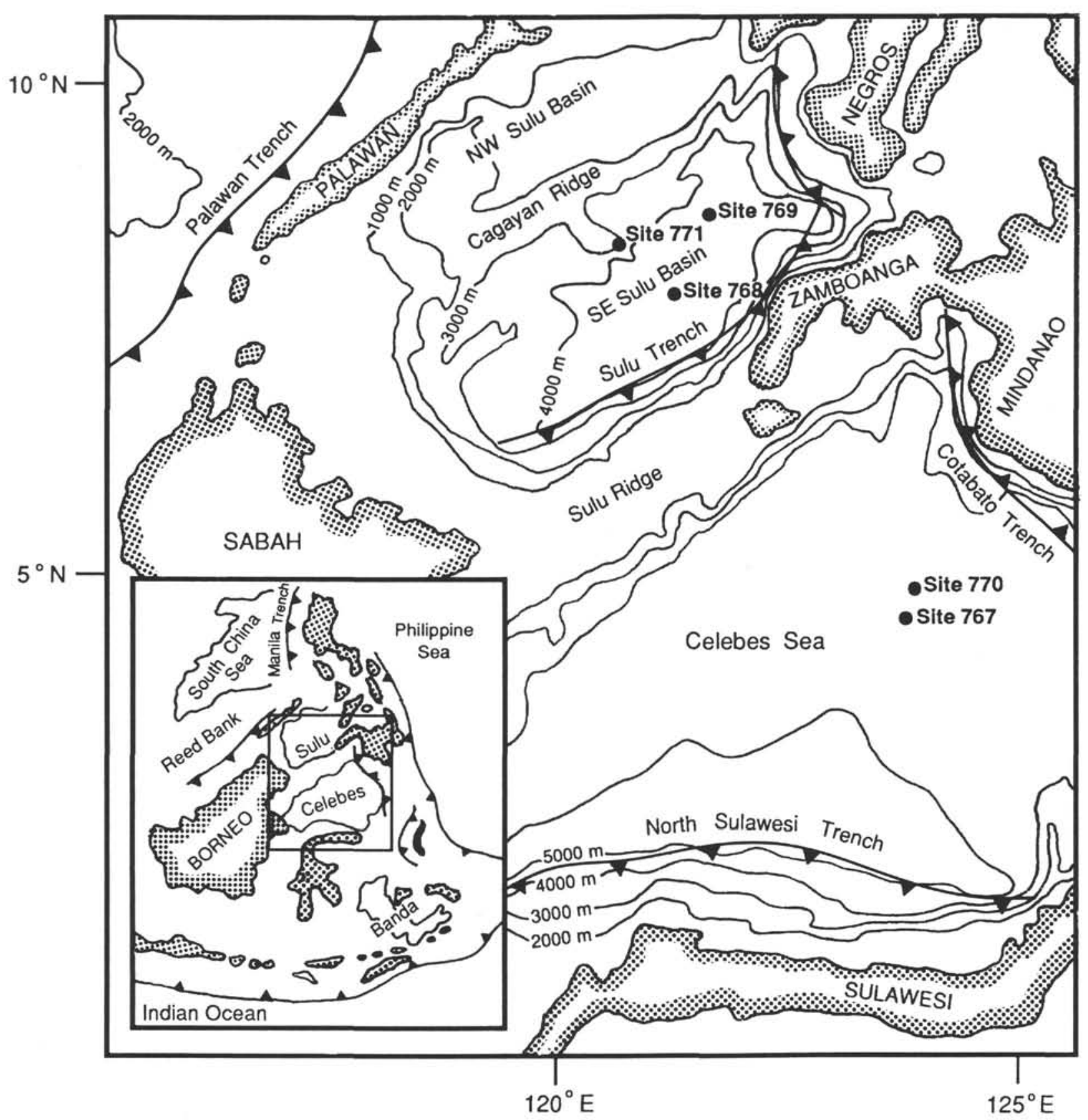

Figure 1. Locations of ODP Leg 124 sites.

zonal markers of Martini's scheme are also recognized and some of them provide useful information for age determinations (Shyu and Mller, this volume). Martini's zonation and all useful biohorizons are listed in Figure 2.

The occurrence and preservation of the calcareous nannofossils in the Celebes Sea were controlled by the water depth of the sites and the presence of the turbidites. At Site 767, which is in the deep Celebes Basin below the carbonate compensation depth (CCD), the calcareous nannofossils are generally well preserved and more abundant in the middle Miocene to Holocene carbonate turbidites, but are very rare or lacking in the interbedded hemipelagic clays, terrigenous turbidites, and the basal pelagic clays. At Site 770 the shallower paleodepth of this site allowed the deposition of thick nannofossil marls and clays from late middle Eocene to late
Oligocene, but dissolution and calcite overgrowth are common.

In the Sulu Basin, calcareous nannofossils are abundant and well preserved in the Quaternary at all three sites. Prior to the Pliocene/Pleistocene boundary, the preservation of calcareous nannofossils deteriorates downward at Sites 768 and 769 , and they disappeared during the early or middle Miocene. Reworked specimens are frequently observed that sometimes make agedetermination more difficult. Site 771 remains above the CCD throughout its depositional history. Calcareous nannofossils are common to abundant and generally well preserved.

\section{Planktonic Foraminifers}

Planktonic foraminifer zones of Blow (1969) were adopted during Leg 124. The ranges of Neogene species are from 
Table 1. Locations of ODP Leg 124 sites.

\begin{tabular}{lccc}
\hline Hole & Latitude $\left({ }^{\circ} \mathrm{N}\right)$ & Longitude $\left({ }^{\circ} \mathrm{E}\right)$ & Water depth $(\mathrm{m})$ \\
\hline $767 \mathrm{~A}$ & $04^{\circ} 47.47^{\prime}$ & $123^{\circ} 30.21^{\prime}$ & 4905 \\
$767 \mathrm{~B}$ & $04^{\circ} 47.47^{\prime}$ & $123^{\circ} 30.20^{\prime}$ & 4905 \\
$767 \mathrm{C}$ & $04^{\circ} 47.50^{\prime}$ & $123^{\circ} 30.21^{\prime}$ & 4905 \\
$768 \mathrm{~A}$ & $08^{\circ} 00.05^{\prime}$ & $121^{\circ} 13.16^{\prime}$ & 4385 \\
$768 \mathrm{~B}$ & $08^{\circ} 00.05^{\prime}$ & $121^{\circ} 13.19^{\prime}$ & 4385 \\
$768 \mathrm{C}$ & $08^{\circ} 00.04^{\prime}$ & $121^{\circ} 13.18^{\prime}$ & 4385 \\
$769 \mathrm{~A}$ & $08^{\circ} 47.14^{\prime}$ & $121^{\circ} 17.65^{\prime}$ & 3644 \\
$769 \mathrm{~B}$ & $08^{\circ} 47.12^{\prime}$ & $121^{\circ} 17.68^{\prime}$ & 3644 \\
$769 \mathrm{C}$ & $08^{\circ} 47.12^{\prime}$ & $121^{\circ} 17.69^{\prime}$ & 3644 \\
$770 \mathrm{~A}$ & $05^{\circ} 08.70^{\prime}$ & $123^{\circ} 40.24^{\prime}$ & 4505 \\
$770 \mathrm{~B}$ & $05^{\circ} 08.69^{\prime}$ & $123^{\circ} 40.10^{\prime}$ & 4505 \\
$770 \mathrm{C}$ & $05^{\circ} 08.69^{\prime}$ & $123^{\circ} 40.11^{\prime}$ & 4505 \\
$771 \mathrm{~A}$ & $08^{\circ} 40.69^{\prime}$ & $120^{\circ} 40.78^{\prime}$ & 2859 \\
\hline
\end{tabular}

Kennett and Srinivasan (1983) and Bolli and Saunders (1985). The ranges of Paleogene species follow the compilation of Toumarkine and Luterbacher (1985).

Planktonic foraminifers are abundant and well preserved in Quaternary nannofossil/planktonic foraminifer marls and oozes in the Sulu Basin. In Pliocene and older sediments, planktonic foraminifers are confined to carbonate and siliciclastic turbidites. Age-diagnostic species are generally absent, so the zonal boundaries can not be defined precisely. In the Celebes Basin, planktonic foraminifers are found as reworked faunas in late Miocene to Quaternary carbonate-rich turbidites and are generally well preserved. In the Paleogene nannofossil marl at Site 770 , planktonic foraminifer assemblages contain only dissolution-resistant forms. Precise zonal assignments cannot be achieved at the Celebes Sea sites because most age-diagnostic species are not preserved.

\section{Deep-water Agglutinated Foraminifers}

Deep-water agglutinated foraminifers were found in the reddish brown claystones in Holes $767 \mathrm{~B}$ and $767 \mathrm{C}$ in the Celebes Sea Basin. Due to the lack of information on the biostratigraphy of the western Pacific Eocene-Oligocene deepwater agglutinated foraminifers, this section was not zoned, but the recovered specimens were separated into three assemblages based on the occurrence of biostratigraphic markers in the Atlantic Ocean and Mediterranean Sea (Kaminski and Huang, this volume). The biostratigraphic correlations of the deep-water agglutinated foraminifers in the Celebes Basin with those in the North Atlantic and Alpine-Carpathian regions indicate an early Eocene age of the basal sediments in the Celebes Basin Site 767.

\section{Diatoms}

Diatoms were of little biostratigraphic use in the Celebes and Sulu Basins. Diatoms are common to abundant and generally well preserved only in the uppermost sediment layers recovered during Leg 124 in the Celebes and Sulu Basins. Preservation of diatoms is poor and abundance is low beneath the upper few meters of sediments in all mud-line cores. Well-preserved diatom assemblages are confined to the Quaternary layers of sediments and are confined to the Pseudoeunotia doliolus and Nitzschia reinholdii Zones (Barron, $1985 \mathrm{a}$; b). The assemblages show distinct neritic characters. Heavily silicified benthic diatoms and diatom fragments were found, in very low abundance, in Pliocene and Quaternary turbidite-rich sediments, indicating downslope transportation. While diatoms were noted in certain Miocene and Oligocene intervals in Sites 769,770 , and 771 , they are too rare and too poorly preserved for reliable biostratigraphic application.

\section{Radiolarians}

Radiolarians are common to abundant in the uppermost Quaternary sediments in the Celebes and Sulu Basins, but as with the diatoms, the siliceous radiolarian tests show severe degradation with depth. With rare exceptions, radiolarians are absent from turbidite-rich Miocene through Pleistocene intervals in the deep basin sites.

A radiolarian assemblage of middle late Miocene age, Didymocyrtis antepenultima Zone, is present at the shallow water Site 770 in the Celebes Basin, in a spot-cored interval. In the Sulu Basin, the late middle to early late Miocene radiolarian assemblages are represented by pyritized specimens of the Diartus petterssoni Zone, found at Sites 769 and 771. All Sulu Sea sites contain late early Miocene radiolarians of the Calocycletta costata Zone, but preservation is generally very poor. The oldest sediments in the Sulu Basin are likely of the Calocycletta costata Zone, but very poor radiolarian preservation makes this determination equivocal. Considering the poor preservation, assignment to the Stichocorys wolffii Zone, possibly older, can not be completely ruled out.

Brown clays in the Celebes Sea sites contain variably preserved radiolarians of late middle Eocene to late Oligocene age. The late early to late Oligocene Dorcadospyris ateuchus Zone is underlain by the early Oligocene Theocyrtis tuberosa Zone. No late Eocene radiolarians have been found. Radiolarians in sediments overlying basement rocks at Site 770 are of the Podocyrtis chalara Zone of the late middle Eocene. A similar assemblage is found overlying basement at Site 767, but preservation is too poor to allow distinction between the Podocyrtis chalara and Podocyrtis goetheana Zones. The radiolarian zonation applied here is mainly from the compilation of Sanfilippo et al. (1985).

\section{Ichthyoliths}

Ichthyoliths are rare and usually found in pelagic clays in samples from all sites with only few exceptions. All of the recognized species have long occurrence ranges and are generally not useful in biostratigraphy. The species identification and age determination of ichthyoliths follow the scheme of Doyle and Riedel (1985).

\section{CHRONOSTRATIGRAPHY}

The chronostratigraphic framework adopted for Leg 124 follows mainly the revised Cenozoic geochronology of Berggren et al. (1985a, b, c) which uses an Anomaly 5-Chron 11 correlation. Diatom biochronology is based on Barron et al. (1985). As diatoms are restricted in the Quaternary sediments in this area, the difference between the geochronologies of Berggren et al. (1985a, b, c) and Barron et al. (1985) will not have any influence on this study. Magnetic reversals are only recorded in the Quaternary sediments at Site 767, in the lower Miocene and Pliocene to Quaternary sediments at Site 768, and in the late Miocene to Quaternary sediments at Site 769. To maintain consistency, determinations of geochronologic unit boundaries are based solely on biostratigraphic datums for Leg 124.

The oldest sediments recovered during this leg are from the Celebes Basin with an age of late middle Eocene, based on the calcareous nannofossils (Site 770), planktonic foraminifers (Site 770), and on radiolarians (Sites 767 and 770). The middle Eocene/late Eocene boundary is placed at $40.0 \mathrm{Ma}$ in the upper portion of Chron $\mathrm{C} 17$ (Berggren et al. 1985a, c) and coincides with the highest occurrence of Chiasmolithus grandis $(40.0 \mathrm{Ma})$. The Eocene/Oligocene boundary is placed at the extinction of Discoaster barbadiensis and Discoaster saipanensis at $36.7 \mathrm{Ma}$ in the lower part of Chron $\mathrm{C} 13$. 


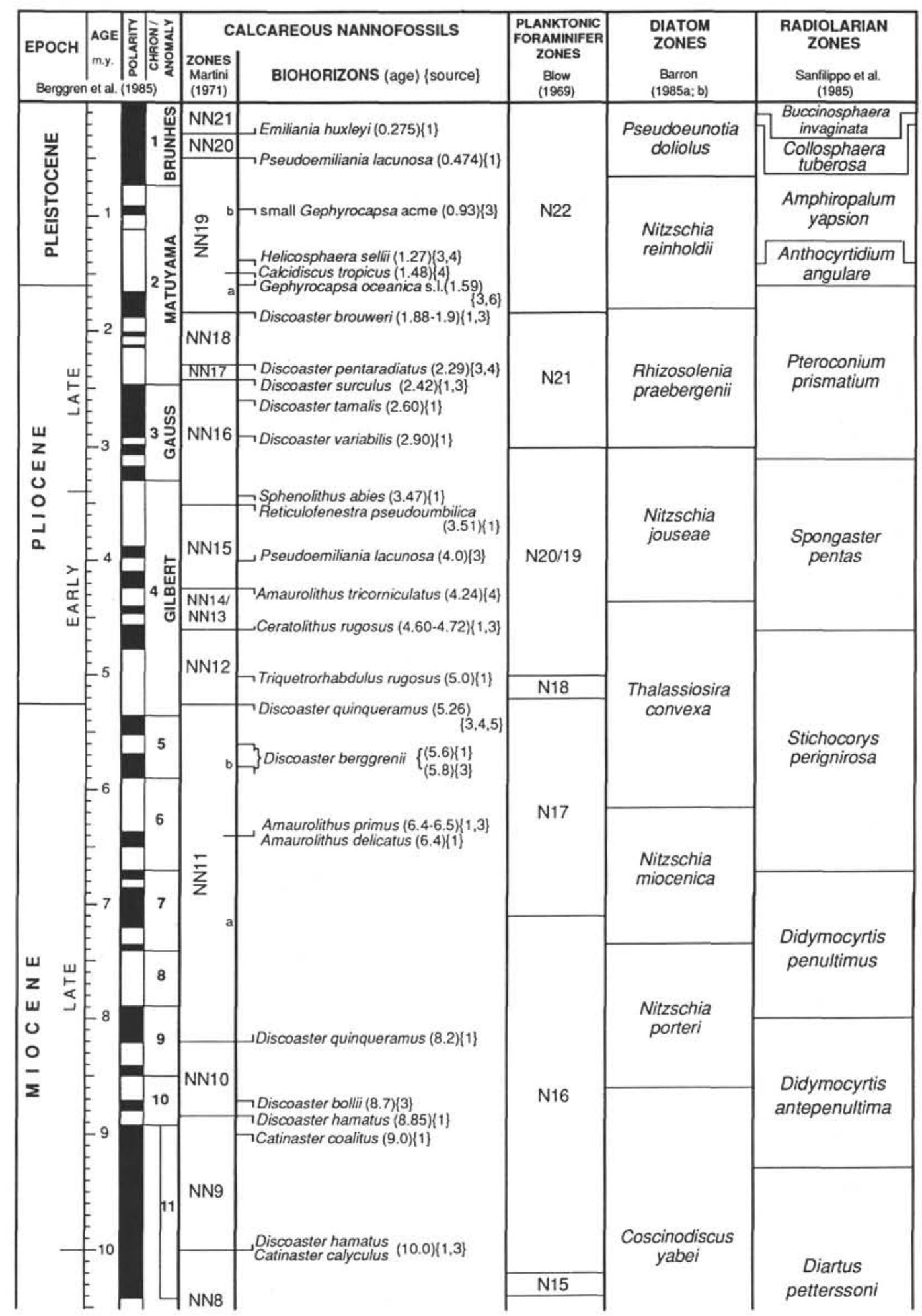

Figure 2. Magnetostratigraphic and biostratigraphic time scale adopted for Leg 124. Correlations follow mainly Berggren, Kent, Flynn, and van Couvering (1985). Age of Reunion Subchron is taken from Harland et al. (1982). Sources of the ages of the calcareous nannofossil biohorizons are: 1. Berggren, Kent, and van Couvering (1985), 2. Berggren, Kent, and Flynn (1985), 3. Gartner (1990), 4. Takayama and Sato (1987), 5. Baldauf et al. (1987), 6. Rio et al. (in press). 


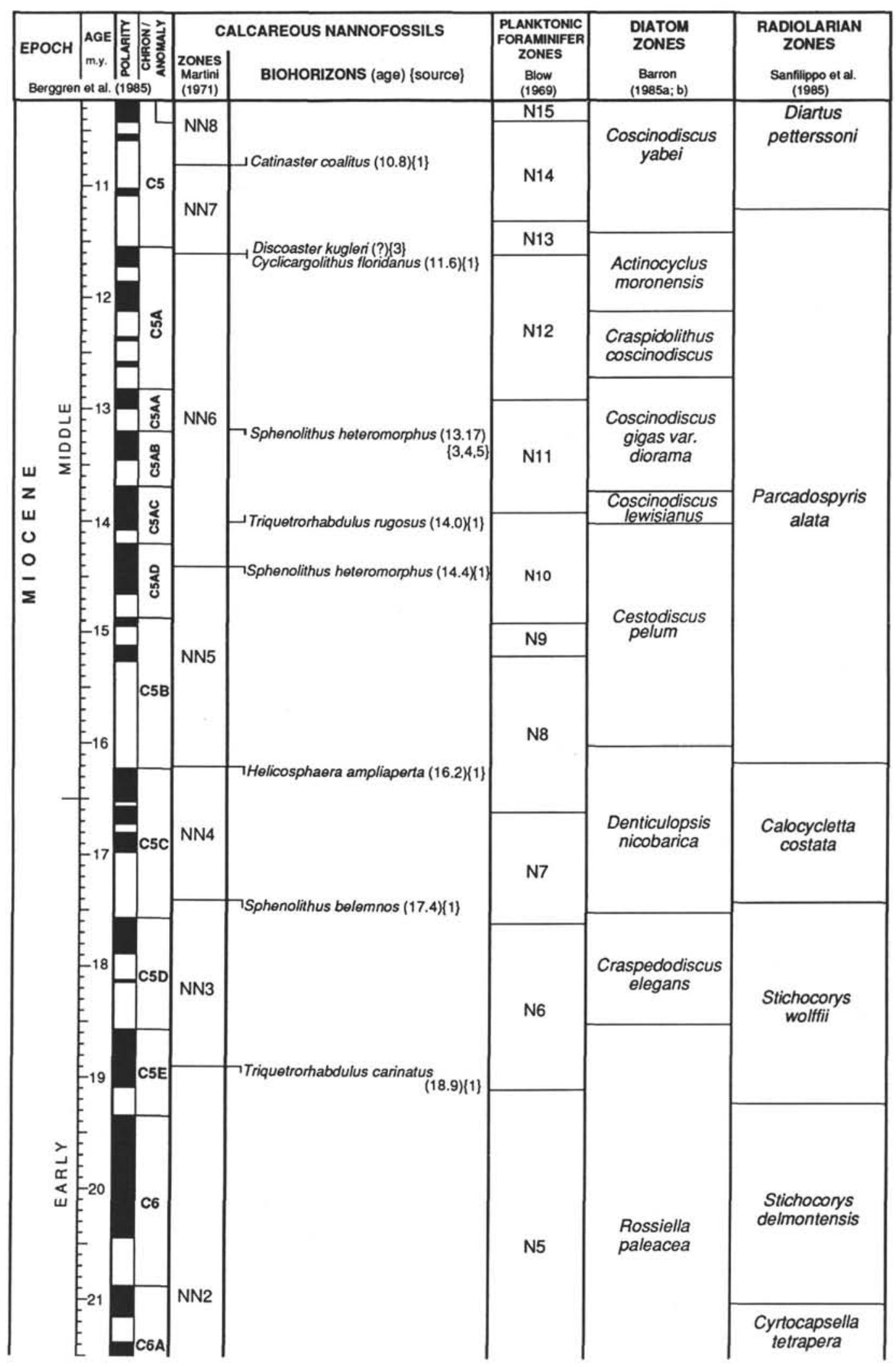

Figure 2 (continued). 


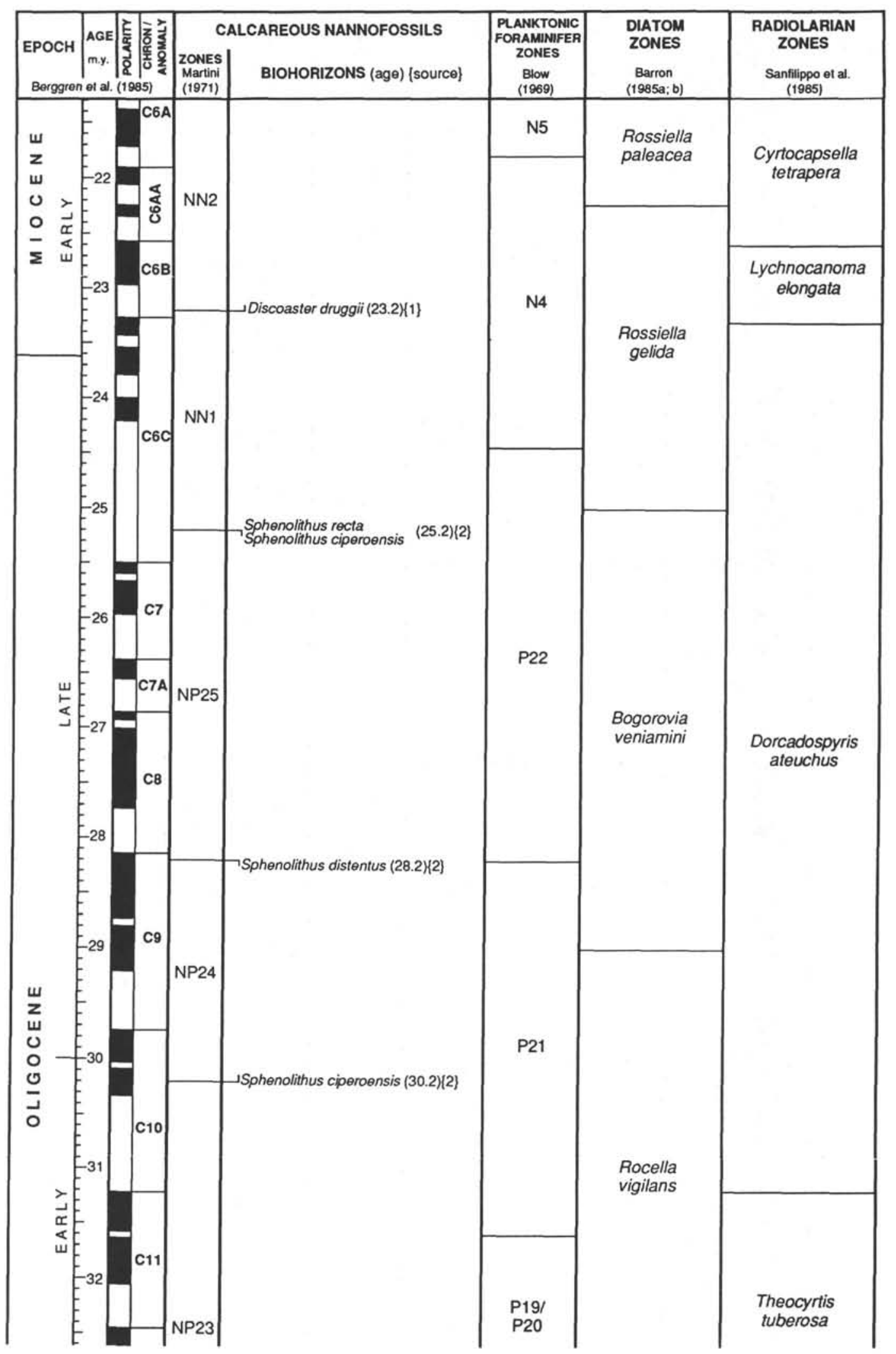

Figure 2 (continued), 


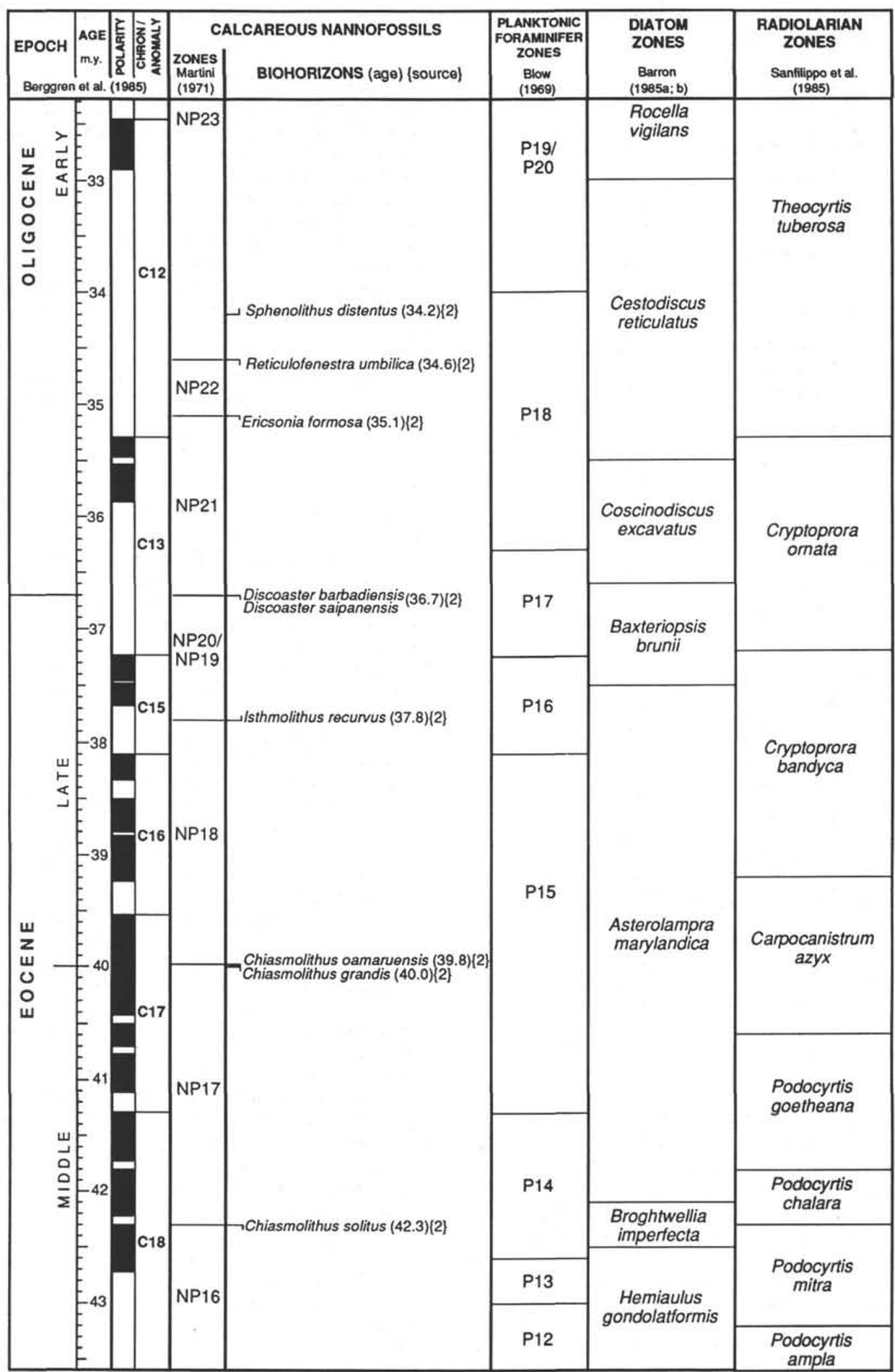

Figure 2 (continued). 
Table 2. Magnetic reversals and theirages adopted for Leg 124 .

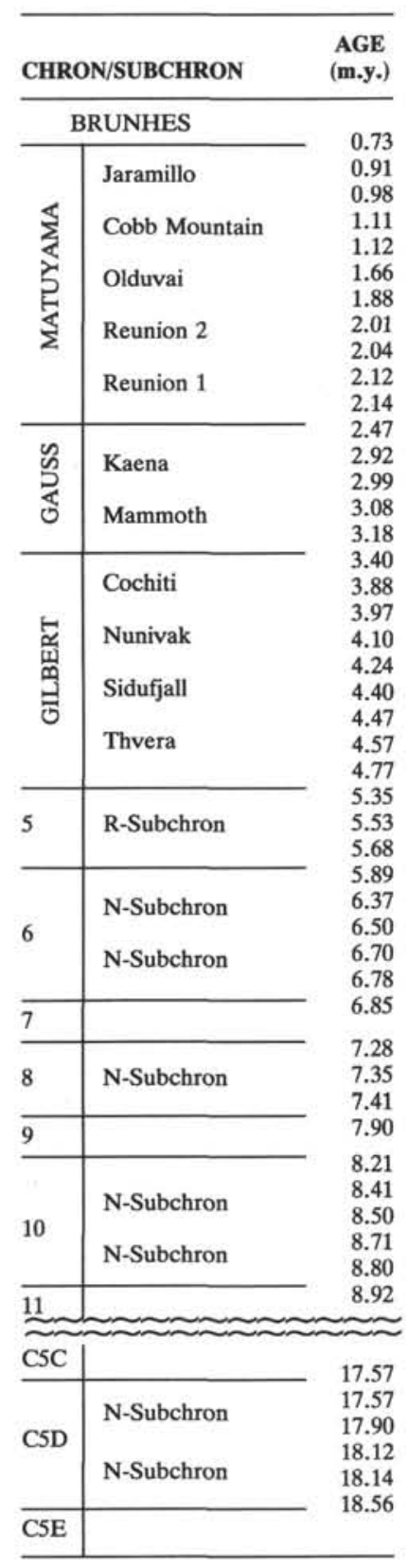

The early Miocene/middle Miocene boundary is placed at 16.5 Ma in the upper part of Chron C5C. This boundary is slightly lower than the bottom of Zone NN5 of Martini (1971) and slightly higher than the top of the Calocycletta costata Zone of Sanfilippo et al. (1985). Berggren et al. (1985b, c) correlate the middle Miocene/late Miocene boundary to the bottom of Chron 11 at $10.4 \mathrm{Ma}$, which is in the middle of nannofossil Zone NN8 and the Diartus petterssoni Zone of radiolarians. It coincides with the boundary between planktonic foraminifer Zones N14 and N15. As magnetic polarity was not recorded down to this level, this boundary is tentatively placed at the top of Zone NN8 during Leg 124 to maintain consistency.

The Miocene/Pliocene boundary is placed above the base of Gilbert Chron (5.35 Ma) and slightly below the top of Zone NN11 (5.26 Ma) at 5.3 Ma (Baldauf et al., 1987; Berggren et al., 1985b, c; Takayama and Sato, 1987). It also falls within the uppermost part of planktonic foraminifer Zone N17. Since calcareous nannofossils is the only fossil group that can be consistently identified at every site within this interval, we choose to use the top of Zone NN11 to mark the Miocene/ Pliocene boundary.

The early Pliocene/late Pliocene boundary, with an age of $3.4 \mathrm{Ma}$ (Berggren et al., 1985b, c), is slightly older than the Gauss/Gilbert boundary and is $0.1 \mathrm{~m}$.y. younger than the top of Zone NN15. The top of Zone NN15 was used to subdivide Pliocene in all Leg 124 cores.

The Pliocene/Pleistocene boundary is one of the most controversial boundaries in the geologic time scale. It is presently accepted by most stratigraphers to be at $1.6 \mathrm{Ma}$, which is within calcareous nannofossil Zone NN19a. In this study, we place this boundary at the lowest occurrence of Gephyrocapsa oceanica s.l. (1.59 Ma), which is just above the top of Olduvai Subchron (Figs. 5 and 6; Shyu and Müller, this volume).

\section{SUMMARY OF BIOSTRATIGRAPHY AND MAGNETOSTRATIGRAPHY}

\section{Celebes Sea}

Site 767

Site 767 is located in the northeast part of the Celebes Basin on a local basement high, in a water depth of $4905 \mathrm{~m}$ (Fig. 1, Table 1). The sediment sequence recovered from the three holes drilled at this site ranges in age from late middle Eocene to Quaternary. The coring record, magnetostratigraphy, biostratigraphic zonations, and geochronologic units are shown in Figure 3. The depths of all magnetic reversal boundaries and biohorizons/events are listed in Table 3.

The magnetic reversal sequence is well determined in all oriented APC cores. The recovered reversals correspond to the Brunhes/Matuyama boundary, the onsets and terminations of the Jaramillo, and the short Cobb Mountain Subchrons. Due to the coring disturbance in XCB and RCB cores, no magnetic reversals can be recognized below Core 124767B-10H (90.5 mbsf).

Site 767 is deposited below the regional CCD and calcareous nannofossils are only present in late Miocene to Quaternary carbonate turbidites at this site. All Quaternary nannofossil zones and a few additional biohorizons were recognized (Fig. 3, Table 3). The acme of small Gephyrocapsa spp. is not present at this site. The Pliocene/Pleistocene boundary based on calcareous nannofossil biostratigraphy was placed at the lowest occurrence of Gephyrocapsa oceanica s.l. in Core 124-767B-15X (132.04 mbsf). The Pliocene zones are defined by the extinctions of marker species. Due to reworking and the scarcity of marker species toward their extinctions, these highest occurrence datum are difficult to determine. The upper boundaries of Zones NN15 to NN18 are determined based on the more consistent occurrence, better preservation, or higher abundance of marker species. No zones can be divided in the early Pliocene because all zonal markers are not preserved and thus a combined Zone NN12-NN15 is assigned to this interval. Late Miocene Zones NN9-NN11 and late middle Miocene Zone NN8 are identified. Although all biohorizons are in the right order of succession, some of them may not be very dependable due to the influences of redeposition and dissolution. No nannofossils are found below Core 124-767B$63 \mathrm{X}$ or in any Hole 767C samples.

Planktonic foraminifers are only found in the calcareous turbidites at Site 767. They are excellently preserved, but as a result of size-sorting during sediment transportation, the assemblages consist mainly of small, globular species that generally have long ranges, and juveniles of larger species. A 
few samples contain rare larger specimens that show signs of dissolution. Precise age determination of planktonic foraminifers at this site is not possible.

The change in coiling direction of Globorotalia menardii occurs between Core 124-767B-13X (111.0 mbsf), which contains predominantly right-coiling specimens, and Core 124767B-18X (161.07 mbsf), which contains mainly left-coiling specimens. This change in coiling direction is here used as an approximation of the lower boundary of Zone N22. The lowest occurrence of Sphaeroidinella dehiscens, the marker of the bottom of Zone N19, is found in Core 124-767B-26X (234.86 mbsf). Left-coiling Pulleniatina spp. are present in Core 124-767B-29X (265.53 mbsf), giving an age of early Pliocene (Zone N18) or older (Stainforth et al., 1975). The small Globorotalia plesiotumida is consistently present in the size-sorted assemblages, and its lowest occurrence in Core 124-767B-36X (336.43 mbsf) is used to mark the lower boundary of late Miocene Zone N17 (Fig. 3).

Benthic foraminifers are found together with planktonic foraminifers in the sediments. Their percentage in the whole foraminifer assemblage increases from about $20 \%$ at the top of Hole $767 \mathrm{~B}$ to a maximum $80 \%$ in Cores 124-767B-24X and $25 \mathrm{X}$, then decreases downward. The increase of benthic foraminifer percentage indicates that more sediments were transported from a much shallower environment by turbidity currents. Foraminifers were not found below Core 124-767B$60 \mathrm{X}$ and in Hole 767C, except for a few agglutinated forms in the reddish brown pelagic clays.

Deep-water agglutinated foraminifers in interval from 678.53 mbsf (Sample 124-767B-72X-3, 23-25 cm) to 704.45 mbsf $(124-767 \mathrm{~B}-75 \mathrm{X}-1,23-25 \mathrm{~cm})$ is characterized by the scattered occurrence of dominantly long-ranging forms (Assemblage 3). However, the occurrence of Reticulophragmium amplectens at the top of this section suggests an age of Oligocene or older. From Sample 124-767B-75X-4, 45-48 cm (706.15 mbsf) to -767C-8R-2, 30-34 cm (745.14 mbsf), the deep-water agglutinated foraminifers assemblage (Assemblage 2) contains typical middle to upper Eocene species in the Atlantic and western Tethys, such as Reophax elongatus, Haplophragmoides walteri walteri, Haplophragmoides horridus, and Karreerulina conversa. Deep-water agglutinated foraminifers are abundant from 753.72 mbsf to $774.50 \mathrm{mbsf}$ (Cores 124-767C-9R to -11R). The assemblage (Assemblage 1) in this interval is dominated by fragments of tubular genera Rhizammina, Rhabdammina, and Bathysiphon but also contains mostly rare and sporadically occurring biostratigraphic markers Spiroplectammina spectabilis, Reophax nodulosus, Kalamopsis grzybowskii, Hormosina ovulum ovulum, Hormosina ovuloides, Rzehakina epigona minima, Hyperammina rugosa, Praecystammina sp., and Paratrochamminoides spp. These marker species indicate an early Eocene age (Kaminski and Huang, this volume). No diagnostic species were found in the sediments directly overlying the basement in Core 124767C-12R.

Diatoms are common and fairly well preserved in the uppermost $2 \mathrm{~m}$ of sediments but become rare and are poorly preserved below the soft, thin surface layer. No diatoms were found below Core 124-767B-9H. One zone of late Quaternary age, the Pseudoeunotia doliolus Zone, is recognized in Cores 124-767B-1H to $124-767 \mathrm{~B}-5 \mathrm{H}$. Benthic diatom species are also found in Site 767 samples, indicating reworking and downslope transport by turbidity currents.

Radiolarians were found in the reddish brown clays that lie beneath turbidite and hemipelagic successions in the Celebes Sea. The highest occurrence of radiolarians at Site 767 was recorded in Section 124-767B-76X-6 (720 mbsf). The poorly preserved assemblage is of the late Oligocene Dorcadospyris ateuchus Zone. This zone ranges down into the late early Oligocene in Sample 124-767C-6R-5, 39-42 cm (734 mbsf). The early Oligocene Theocyrtis tuberosa Zone was recognized from Sample 124-767B-78R, CC (739.0 mbsf) down to Sample 124767C-11R, CC (782.1 mbsf). Core recovery and radiolarian preservation are both very poor in this interval. Abundant but very poorly preserved radiolarians in the lowermost $4 \mathrm{~m}$ of sediments (783.0-786.92 mbsf), in Core 124-767C-12R, include specimens suggesting a late middle Eocene succession of the Podocyrtis chalara Zone or Podocyrtis goetheana Zone. Identification of these radiolarian zones constrains the age of basement to the late middle Eocene at approximately $42 \mathrm{Ma}$ or older.

Ichthyoliths were found in Cores 124-767B-64X to $-78 \mathrm{X}$ and in Cores 124-767C-3R to -12R. They are mostly rare in the samples and only allow for general age determination. "Small triangle crenate margin," an Eocene to early Oligocene form, was encountered at 733 mbsf in the red clays in Core 124767B-78X. "Small dendritic many radiating lines," an early Oligocene to Holocene form, was encountered in Sample 124-767C-6R, CC (735 mbsf). The occurrence of these two specimens indicates an early Oligocene age for this level. "Triangle hooked margin" was found in the core catchers of Cores 124-767C-11R and $-12 R$. This type of ichthyoliths first occurred at the beginning of the Eocene and its presence in the sediments immediately overlying the basalt in Section 124767C-12R, CC (791.7 mbsf) indicates a Eocene or younger age for the basement.

\section{Site 770}

Site 770 is located on a raised fault block $45 \mathrm{~km}$ north of Site 767 and is $400 \mathrm{~m}$ shallower (Fig. 1, Table 1). The main purpose of drilling this site was to collect basement rock samples to accomplish the objectives of Site 767. Three holes were drilled at this site. The top $340.9 \mathrm{~m}$ of sediments were spot cored, and continuous RCB cores were taken from 340.9 mbsf to 529.5 mbsf in Holes $770 \mathrm{~B}$ and $770 \mathrm{C}$. Paleomagnetic measurement at this site was restricted to examine changes in inclination. The inclination data are too scattered and, therefore, no magnetic reversals can be identified. The coring record, biostratigraphic zonations, and geochronologic units are shown in Figure 4. The depths of all biohorizons/events are listed in Table 4.

The Neogene sediment sequence at Site 770 was deposited below the regional $\mathrm{CCD}$ and the calcareous fossils are not preserved in most of the Neogene sediments except in Core 124-770B-4R. Rare planktonic foraminifers (Globorotalia tumida, Sphaeroidinella dehiscens, and Globoquadrina altispira) and calcareous nannofossils (Discoaster assymetricus, Discoaster brouweri, Discoaster pentaradiatus, Discoaster surculus, Sphenolithus abies, Pseudoemiliania lacunosa, Ceratolithus rugosus, and Reticulofenestra pseudoumbilica) in this core indicate an early Pliocene age (Zones N19/N20 and NN15). Very few agglutinated foraminifers were found in the red clay and reddish marl sequence from Cores 124-770B-8R through 124-770B-12R.

Diatoms and radiolarians are common in the surface sediments. The late Quaternary Pseudoeunotia doliolus Zone is recognized in Cores 124-770A-1R and -770B-1R. Only rare diatom fragments occur sporadically below the first core and no age-diagnostic species were found.

During its earliest history, Site 770 was deposited very close to, but for most of the time above, the CCD. The major lithology in Cores 124-770B-13R through $-16 \mathrm{R}$ is reddish nannofossil marl that contains common to abundant calcareous fossils. A late Oligocene age (Zone NP25) was assigned to the calcareous nannofossil assemblage in Section 124-770B11R-1, $70 \mathrm{~cm}$ (369.6 mbsf). 


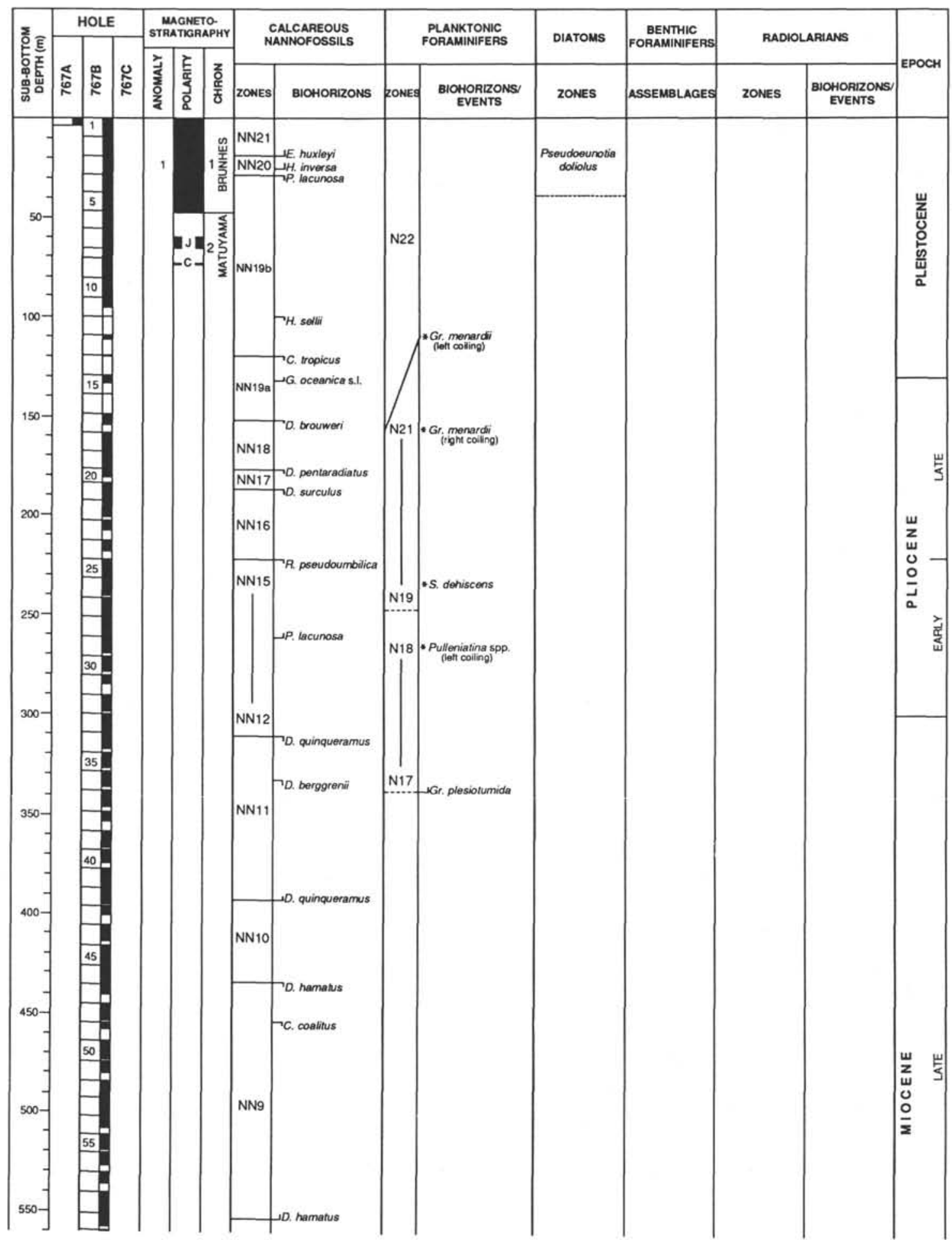

Figure 3. Coring record, magnetostratigraphy, and biostratigraphic zonations at Site 767. Dotted line in "zones" column indicates uncertain boundary. ${ }^{*}=$ occurrence of marker species.

An undifferentiated Oligocene Zone NP23-NP24 was encountered at the top of Core 770B-13R (389.34 mbsf) based on the occurrence of Sphenolithus distentus and Sphenolithus predistentus, and the absence of Sphenolithus ciperoensis and Reticulofenestra umbilica. Two early Oligocene Zones NP22 and NP21 were identified in Core 124-770B-14R.

The top of the Eocene is placed in the top of Core 124-770B-15R (407.95 mbsf) at the highest occurrences of
Discoaster barbadiensis and Discoaster saipanensis. No marker species were found to separate Zones NP18, NP19, and NP20. The marker for the top of Zone NP17, the highest occurrence of Chiasmolithus oamaruensis, was not found, so a slightly older $(0.2 \mathrm{~m}$.y. $)$ biohorizon-the highest occurrence of Chiasmolithus grandis, was used to separate Zone NP17 from NP18 and mark the boundary between late and middle Eocene in Sample 124-770B-15R-3, 146-147 cm (412.06 mbsf). 


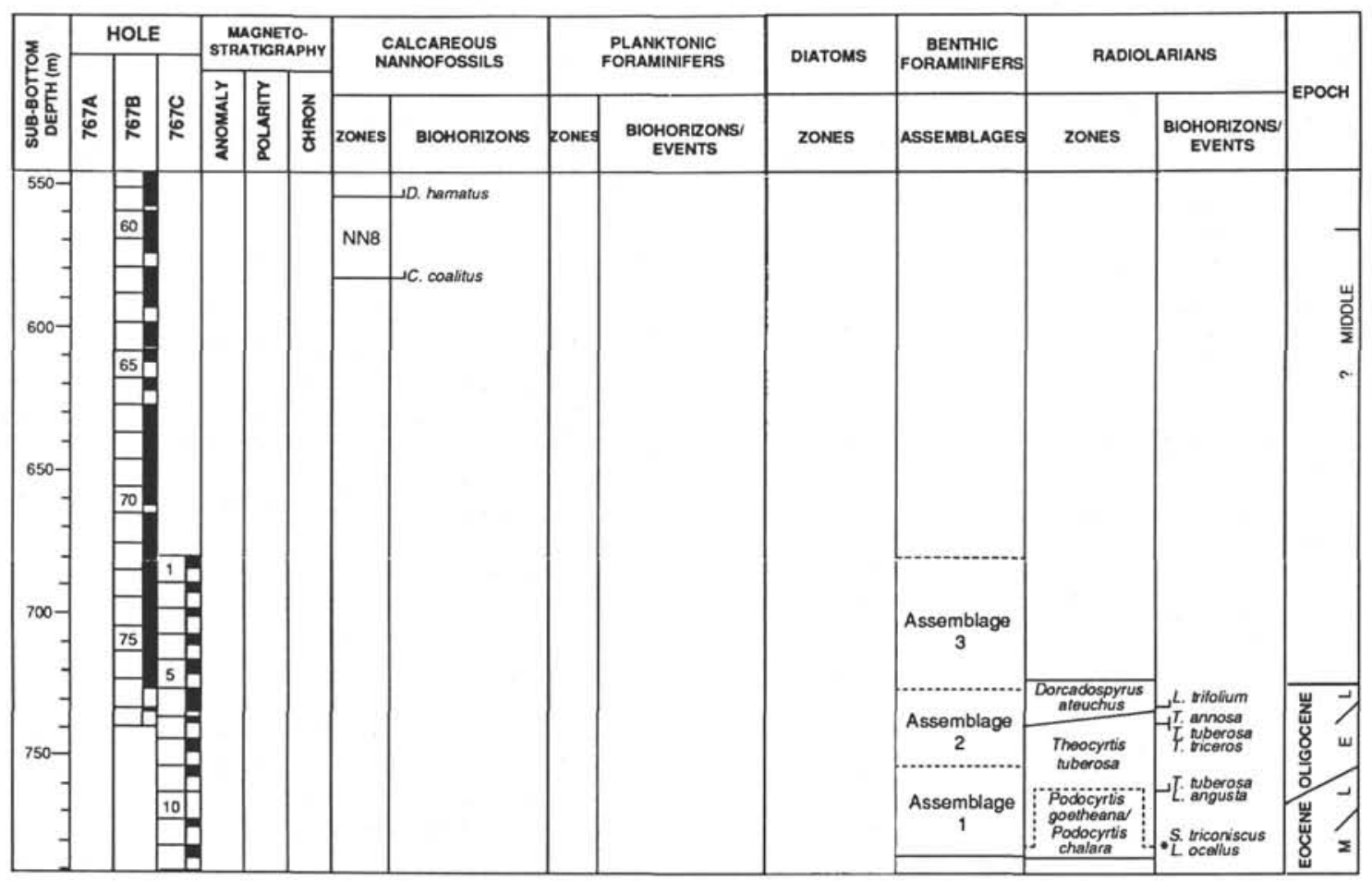

Figure 3 (continued).

Zone NP17 continues down to Sample 124-770B-16R-3, 29-30 $\mathrm{cm}$ (420.6 mbsf), which is only $30 \mathrm{~cm}$ above the basement. It thus appears that the age of the basement is older than $40 \mathrm{Ma}$ but younger than $42.3 \mathrm{Ma}$ (Berggren et al., 1985b).

The planktonic foraminifers found in the Paleogene sediments consist of dissolution-resistant forms only, and most of the age-diagnostic species are not preserved. As a result, the Oligocene and late Eocene zones can not be divided at this site. The upper part of the late middle Eocene Zone P14 was identified in Samples 124-770B-15R-4, 100-103 cm (413.1 mbsf), and -15R, CC (417.3 mbsf), by the co-occurrence of Globigerina senni and Globorotalia opima nana. The oldest sample to yield foraminifers contains Catapsydrax dissimilis, which indicates a late middle Eocene age (P14 or P13).

Due to the very low diversity and abundance of marker species, dating with radiolarians is very difficult in Cores $124-770 \mathrm{~B}-10 \mathrm{R}$ to $-12 \mathrm{R}$. But the preservation of radiolarians is surprisingly good, with fine spines and other delicate features fully preserved compared with the poorly-preserved radiolarians found in the same time-stratigraphic interval at Site 767. This significant difference in radiolarian preservation may be related to the shallower paleodepth of Site 770 , which was probably more than $400 \mathrm{~m}$ shallower than Site 767 during the late Oligocene and earliest Miocene (Rangin, Silver, von Breymann, et al., 1990).

A well-preserved early late Miocene radiolarian assemblage was found in the spot-cored interval in Core 124$770 \mathrm{~B}-6 \mathrm{R}$ and is assigned to the upper part of the Didymocyrtis antepenultima Zone. The next lower occurrence of radiolarians is in Sample 124-770B-10R-3, 125-130 cm (363.6 mbsf). The assemblage suggests a late Oligocene age in the Dorcadospyris ateuchus Zone. The Dorcadospyris ateuchus Zone is recognized down through Core 124-770B-11R (378.6 mbsf). The early Oligocene Theocyrtis tuberosa Zone is found in Cores 124-770B-12R through -14R and in Core 124-770C-1R. A diverse and moderately well-preserved late middle Eocene radiolarian assemblage of the Podocyrtis chalara Zone is found in a 1-cm layer in Sample 124-770B-16R-3, 42-43 cm (420.72-420.73 mbsf). This assemblage directly overlies a thin pyroclastic unit and is about $22 \mathrm{~cm}$ above the basalt.

Ichthyoliths occur throughout the sediment columns with very low abundances and poor preservations. No age-diagnostic forms were found and they are biostratigraphically useless at this site.

\section{Sulu Sea}

\section{Site 768}

Site 768 is located in the center of the southeast Sulu Basin, below $4395.3 \mathrm{~m}$ of seawater (Fig. 1, Table 1). Three holes were drilled at this site. The coring record, magnetostratigraphy, biostratigraphic zonations, and geochronologic units are shown in Figure 5. The depth of all magnetic reversal boundaries and biohorizons/events are listed in Table 5 .

The upper $210 \mathrm{~m}$ of sediments were penetrated by APC coring with $100 \%$ recovery. All magnetic reversals younger than the Thvera Subchron are easily identified with the exception of the lower part of the two Reunion Subchrons. The magnetic intensity sharply dropped about three orders of magnitude from $10 \mathrm{~mA} / \mathrm{m}$ to $0.01 \mathrm{~mA} / \mathrm{m}$ at a depth near 188 mbsf $(124-768 \mathrm{~B}-20 \mathrm{H}-3,170 \mathrm{~cm})$. The determination of magnetic reversals below this level was based on two characteristics: (1) direction stays on normal during normal polarity but scatters in reversed polarity, (2) intensity tends to be weaker during reversed polarity than during normal polarity. The reversal depths determined by this method are close to the expected depth obtained from a linear age-depth relation.

No magnetic reversals can be identified below Core 124$768 \mathrm{~B}-24 \mathrm{X}$ because the magnetic polarity directions in the XCB cores are too scattered and the magnetic intensities in discrete samples are too low. Magnetic measurement obtained better results in the pyroclastic unit in RCB cores below Core 
Table 3. Magnetic reversal datums and biostratigraphic biohorizons/events at Site 767.

\section{SITE 767}

CALCAREOUS NANNOFOSSILS: BIOHORIZONS *

DEPTH (mbsf)

L.O.

L.O.

$$
\text { Emiliania huxleyi }
$$

18.50

Helocosphaera inversa

25.47

Pseudoemiliania lacunosa

28.25

Helicosphaera sellii

Calcidiscus tropicus

Gephyrocapsa oceanica s.1.

100.00

119.43

132.04

152.70

Discoaster brouweri

Discoaster pentaradiatus

Discoaster surculus

171.49

187.04

Reticulofenestra pseudoumbilica $\quad 222.90$

Amaurolithus delicatus

222.90

261.68

Pseudoemiliania lacunosa

$\begin{array}{ll}\text { Amaurolithus tricorniculatus } & 261.68 \\ \text { Discoaster quinqueramus } & 311.78\end{array}$

$\begin{array}{ll}\text { Discoaster quinqueramus } & 311.78 \\ \text { Discoaster berggrenii } & 333.12\end{array}$

Discoaster quinqueramus

333.12

433.97

Discoaster hamatus

433.97
553.56

Discoaster hamatus

582.51

L.O. Catinaster coalitus

PLANKTONIC FORAMINIFERS: BIOHORIZONS/EVENTS* DEPTH (mbsf)

\begin{tabular}{lll}
\hline O. & left coiling Globorotalia menardii & 111.00 \\
O. & right coiling Globorotalia menardii & 161.07 \\
O. & Sphaeroidinella dehiscens & 234.86 \\
H.O. & left coiling Pulleniatina & 265.53 \\
L.O. & Globorotalia plesiotumida & 336.43
\end{tabular}

RADIOLARIANS

\begin{tabular}{llc} 
& BIOHORIZONS/EVENTS* & DEPTH (mbsf) \\
\hline L.O. & Lychnocanoma trifolium & 732.9 \\
L.O. & Theocyrtis annosa & 739.0 \\
H.O. & Theocyrtis tuberosa & 739.0 \\
H.O. & Tristylospyris triceros & 739.0 \\
L.O. & Theocyrtis tuberosa & 762.7 \\
L.O. & Lithocyclia angusta & 762.7 \\
Co-O. & Sethochytris triconiscus \& & 783.0 \\
& Lithocyclia ocellus &
\end{tabular}

MAGNETIC REVERSALS:

$$
\text { REVERSALS }
$$

DEPTH (mbsf)

BRUNHES/MATUYAMA

Top Jaramillo

Bottom Jaramillo

Top Cobb Mountain

Bottom Cobb Mountain

48.8

60.2

66.4

74.0

75.0

*L.O = lowest occurrence, H.O. = highest occurrence, Co-O.= co-occurrence, $\mathrm{O}_{2}=$ occurrence.

124-768C-47R (810-1030 mbsf). This interval is interpreted as Chron $\mathrm{C} 5 \mathrm{C}$ to Chron $\mathrm{C} 5 \mathrm{E}$ based on the correlation with radiolarian biostratigraphy.

Sediments recovered at Site 768 contain radiolarians in the late Quaternary and in the late early Miocene. The thick, turbidite-rich middle Miocene through Pleistocene sections contains only very rare and likely allochthonous radiolarians. The only pre-Pleistocene radiolarian zone that is confidently identified is the Calocycletta costata Zone in an abundant, moderately well-preserved radiolarian assemblage recovered in the reddish brown pelagic claystones in Cores 124-768C$47 \mathrm{R}$ and $-48 \mathrm{R}$. Below this, Calocycletta costata has not been identified, but it is impossible to determine with confidence whether the lack of identifiable Calocycletta costata is diag- nostic or an artifact of poor preservation. A thick pyroclastic sequence ( 816 through $1050 \mathrm{mbsf}$ ) was recovered overlying basement rocks. Minor claystones above, within, and below the pyroclastics include very rare and very poorly preserved radiolarians. Few, if any, specimens can be identified with certainty, but the radiolarian remains that can be tentatively identified suggest the late early Miocene Calocycletta costata Zone to Stichocorys wolffii Zone. The lower boundary of the Calocycletta costata Zone is placed at $17.3 \mathrm{Ma}$ in previous publications (Barron, 1985a, b; Barron et al., 1985; Berggren et al, 1985a, c). In Hole 768C, the lowest identifiable Calocycletta costata is found in Section 124-768C-48R-3 at the top of a normal polarity interval that was interpreted as the highest normal polarity in Chron C5D based on the magnetic reversal pattern and the correlation with radiolarian zone. The overlying reversed polarity in Core $124-768 \mathrm{C}-48 \mathrm{R}$ is thus assigned to Chron C5C and the normal polarity in Core $124-768 \mathrm{C}-67 \mathrm{R}$ is assigned to Chron C5E.

Calcareous nannofossils are common to abundant and are generally well preserved in the Quaternary nannofossil and foraminifer marls and oozes. All useful biohorizons are identified and are in the right order of succession except the highest occurrence of Calcidiscus tropicus. The extinction of Calcidiscus tropicus should be about $0.2 \mathrm{~m}$.y. later than the end of the Olduvai Subchron (Berggren et al., 1985a, b, c) but this species tends to disappear earlier at this site, before the end of the Olduvai Subchron.

The preservation of nannofossils deteriorates in the Pliocene and the assemblages show signs of dissolution. All late Pliocene zones can be recognized but there is only one early Pliocene marker species present, and the division of Zones NN13 to NN15 is impossible. The accumulation rate becomes very high in the late Miocene, and all zones from NN9 to NN11 are very thick. This increase of accumulation rate was caused by a significant increase of turbidite deposition. The turbidite beds constitute about $75 \%$ of the entire lower upper Miocene sediment sequence but the thickness and frequency of turbidite beds steadily decrease upward, and only very rare turbidite beds were found in the Pliocene (Rangin, Silver, von Breymann, et al., 1990). Nannofossils are less abundant and their preservation continues to deteriorate downward. The accumulation rate decreases sharply in the middle Miocene. Zone NN9 lasts for about $1.15 \mathrm{~m} . \mathrm{y}$. and is only 0.35 m.y. longer than Zone NN8 (Berggren et al., 1985c). But in this hole, Zone NN8 is much thinner than Zone NN9 (Fig. 5). The lithology below late Miocene also become dominantly claystones.

Two thin turbidite beds in Core 124-768C-42R contain early to middle Miocene calcareous nannofossil species including Sphenolithus heteromorphus, Cyclicargolithus floridanus, and Discoaster deflanderi. Although there is no sufficient data to define a zone, the occurrences of these species indicate a possible age of Zone NN4 (late early Miocene) or NN5 (early middle Miocene). This interpretation is supported by radiolarians and magnetic polarities that also indicate that the early Miocene/middle Miocene boundary is above Core 124-768C-47R. These datums imply that less than $55 \mathrm{~m}$ of sediments were deposited in about $4 \mathrm{~m}$.y., which could be the result of a sharp decrease in sediment supply or the presence of hiatus.

Planktonic foraminifers are abundant and well preserved in Quaternary sediments but most of the marker species are missing. The highest occurrence of the pink variety of Globigerinoides ruber is found in Section 768B-2H, CC (13.5 mbsf). In the Pacific and Indian Oceans, this event occurred at approximately $0.12 \mathrm{Ma}$ (Thompson et al., 1979). Globigerinoides obliquus occurs highest in Sample 124-768B-13H-2, 
$70-72 \mathrm{~cm}$ ( $110.7 \mathrm{mbsf})$ that is slightly higher than the top of the Olduvai Subchron. With the absence of the zonal marker Globorotalia truncatulinoides, the base of Zone N22 is tentatively placed at the change in coiling direction of Globorotalia menardii s.l. at the bottom of Core 124-768B-14H (124.52 mbsf). The preservation of planktonic foraminifers deteriorates downhole around this level. Below Core 124-768B-15H they are only preserved in carbonate and siliciclastic turbidites deposited below the CCD, and the assemblages consist mainly of displaced, size-sorted specimens with very rare age-diagnostic species. The foraminifers found in Sample 124-768B-17H-4, 54-59 cm (151.54 mbsf) indicate an early late Pliocene age (Zone N19-21) by the presence of Sphaeroidinella dehiscens, the occurrence of Globorotalia tumida and Globorotalia margaritae in Core 124-768B-19H indicate an early Pliocene age of Zone N18. The lowest occurrence of Globorotalia plesiotumida in the core-catcher of Core 124-768B-36X (340.37 mbsf) marks the lower boundary of late Miocene Zone N17. The presence of Neogloboquadrina acostaensis in Sample 124-768C-1R-4, 41-45 cm (357.11 mbsf) indicates a late Miocene age (Zone N16). Benthic foraminifers are rare in Hole $768 \mathrm{~B}$ and only agglutinated forms were found in Hole $768 \mathrm{C}$.

Diatoms are well preserved in the top $60 \mathrm{~cm}$ of the light brown soupy unit at Site 768. The assemblage represents the late Pleistocene Pseudoeunotia doliolus Zone. Diatoms degrade rapidly downward and only severely dissolved fragments are found in the sediments. No diatoms were found below Core 124-768B-7H (50 mbsf).

Ichthyoliths occur only in the pelagic clays in Hole $768 \mathrm{C}$. The presence of "small triangle many striations together" and "flexed triangle shallow in base 120 " in Section 124-768C-40R, CC (739.6 mbsf), indicates an early or middle Miocene age. Otherwise, no detailed ages were obtained from ichthyoliths.

\section{Site 769}

Site 769 was chosen on a tilted fault block on the southeast flank of Cagayan Ridge at $3643 \mathrm{~m}$ water depth (Fig. 1, Table 1). Three holes were drilled at this site. The coring record, magnetostratigraphy, biostratigraphic zonations, and geochronologic units are shown in Figure 6. The depths of all geomagnetic reversal boundaries and biohorizons/events are listed in Table 6.

The upper $220 \mathrm{~m}$ of sediments were retrieved by APC coring and recovery was almost $100 \%$. The magnetic records in Holes 769A and 769B are fairly good with only a few exceptions. The Cobb Mountain Subchron was not observed at this site due to the scattered magnetic directions caused by slumped beds in the bottom half of Core 124-769B-10H (86.5-90.6 mbsf). Reversals are also difficult to identify between 115 and $130 \mathrm{mbsf}$ because of the occurrence of slumped beds. A short normal interval recognized from 114.5 mbsf (124-769B-13H-4, $10 \mathrm{~cm})$ to 117.5 mbsf (124-769B-13H-6, 10 $\mathrm{cm}$ ) is interpreted as the interval between the Kaena and Mammoth Subchrons. This interpretation gives a constant accumulation rate to this interval and also makes the assignment of the next normal subchron to the lowest part of the Gauss Chron fairly reasonable. The top of the Gauss Chron was tentatively placed at about 107 mbsf (Section 124-769B$12 \mathrm{H}-5,60 \mathrm{~cm}$ ) and the bottom was interpreted at $126 \mathrm{mbsf}$ (Section 124-769B-14H-5, 60 cm). The tops of the Kaena and Cochiti Subchrons and the bottom of the Mammoth Subchron can not be determined at this site. From the bottom of the Cochiti Subchron to the end of the APC cores, 26 geomagnetic reversals were recognized (Fig. 6, Table 6). The oldest reversal encountered at 213.5 mbsf (Section 124-769B-24H-2, 70 $\mathrm{cm}$ ) represents the Chron $11 /$ Chron 10 boundary.
All calcareous nannofossil zones from NN21 to NN9 were identified except in the early Pliocene. Zones NN12-15 were combined because all early Pliocene markers are very poorly preserved and the separation of zones is impossible. Calcareous nannofossils are common to abundant in the Pleistocene and late Pliocene but may be rare or lacking in most of the early Pliocene to middle Miocene samples. Zone NN8 was recognized in Sample 124-769B-25X-3, 62-63 cm (224.42 mbsf) through 124-769B-25X-4, 97-98 cm (226.27 mbsf), indicating a late middle Miocene age. Below this level, no diagnostic species was found and nannofossils become very rare. The lowest occurrence of nannofossils is in Core 124769B-26X.

Planktonic foraminifers are abundant and well preserved in the top $100 \mathrm{~m}$ of sediments (down to Core 124-769B-11H). The highest occurrence of pink Globigerinoides ruber is found in Sample 124-769A-2H-1, 65-67 cm (9.05 mbsf), and the highest occurrence of Globigerinoides obliquus is found in Sample 124-769B-11H-4, 59-61 cm (95.99 mbsf). In Core 124-769B$12 \mathrm{H}$ (105.7 mbsf) the coiling direction of Globorotalia menardii changes to predominantly right. As at Site 768, the preservation of planktonic foraminifers at this site also rapidly deteriorates below this level and all underlying sediments are deposited below the regional CCD. The lowest occurrence of Globorotalia plesiotumida, the marker of the base of Zone N17, was found in Section 124-769B-21H, CC (192.3 mbsf). Below this level, the presence of Globorotalia siakensis in Core 124-769B-25X (226.24 mbsf) suggests middle Miocene Zone $\mathrm{N} 14$ as the youngest possible age. Planktonic foraminifers are preserved only in carbonate-rich turbidites in Cores 124-769B-15H through -25X, and the preservations are generally poor. Consequently, biostratigraphic markers are rare and age determinations are extremely difficult.

Diatoms are abundant in the uppermost $60 \mathrm{~cm}$ of sediments and are rare and generally poorly preserved below. Two zones were recognized at this site. The Pseudoeunotia doliolus Zone was identified from the top to 59.9 mbsf (769B-7H-3, $96 \mathrm{~cm}$ ) and Nitzschia reinholdii Zone was encountered from Sections 124-769B-7H, CC (62.4 mbsf) through -11H, CC (100.4 mbsf). The boundary between the two zones is not clear but is in the lower part of the Brunhes Chron, which is in good agreement with the age given by previous paleomagnetic-diatoms correlation (Barron et al., 1985).

Radiolarians were found in the late Neogene sediment sections of Site 769 , but the preservation is poor and the abundance is generally low. A late middle Miocene assemblage of the Diartus petterssoni Zone, preserved by pyritization of the siliceous skeletons, is present in Core 124-769B$25 \mathrm{X}$ (230.3 mbsf). Very poorly preserved radiolarians were found in Cores 124-769B-29X (265 mbsf) to the top of pyroclastic sediments below Core 124-769C-2R. These radiolarian remains cannot be zoned, but they appear to reflect Calocycletta costata to Stichocorys wolffii Zones, as with Site 768. No radiolarians were found below Sample 124-769C-2R, CC ( $280.5 \mathrm{mbsf}$ ), except as drilling breccia at the tops of several cores within the pyroclastic unit.

Ichthyoliths are very rare in the gray clays in Hole 769B. No useful biostratigraphic markers are present at this site.

\section{Site 771}

Site 771 is located on a large plateau on the east flank of Cagayan Ridge about $30 \mathrm{~km}$ northwest of Site 768 (Fig. 1, Table 1). One hole was drilled at this site to complement Site 769. The first core was taken at 100 mbsf and continuous RCB cores were retrieved from 144.7 to 304.1 mbsf. Due to the severe disturbance in RCB coring, sediments recovered at this site did not provide sufficient paleomagnetic data for magnetic 


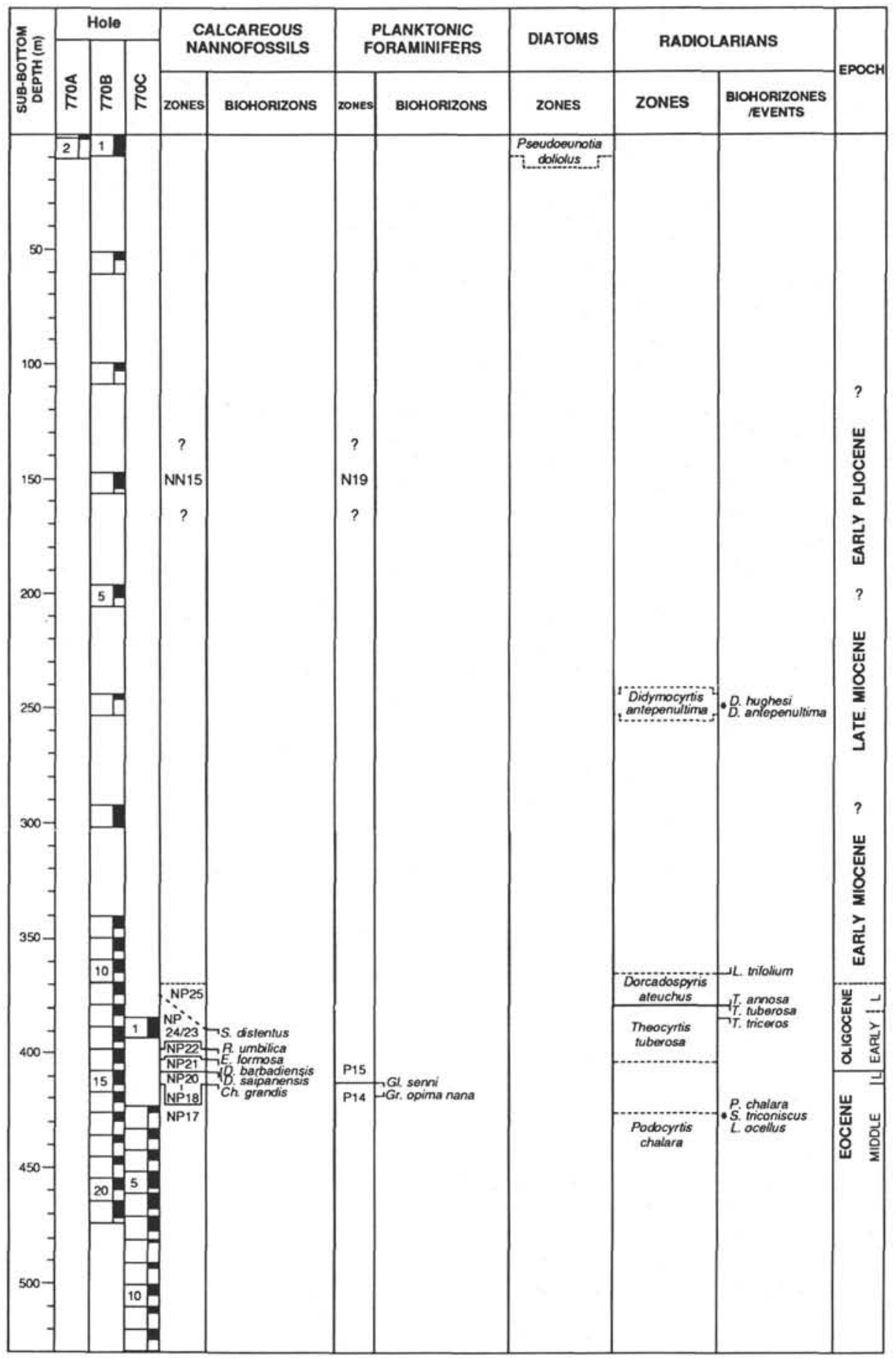

Figure 4. Coring record and biostratigraphic zonations at Site 770. Dotted line in "zones" column indicate uncertain boundary. ${ }^{*}=$ occurrence of marker species.

reversal determination. The coring record, biostratigraphic zonations, and geochronologic units are shown in Figure 7. The depths of all biohorizons/events are listed in Table 7.

Site 771 is only $2856 \mathrm{~m}$ below sea level and all recovered sediments were deposited above the CCD. An early-late Pliocene to early middle Miocene calcareous nannofossil clay and marl contain common to abundant calcareous nannofossils, which allows identification of all Zones from NN5 to NN16 except the NN13/NN14 boundary. In a few samples in the pyroclastic sediments and lapillistones below Core 124-
771A-11R, very rare nannofossil specimens representing Zones NN3 to NN5 were also found, but no zonal boundaries can be drawn and the reliability of those species are unknown.

Planktonic foraminifers are present throughout the sediment sections at Site 771. Although most samples show signs of dissolution and fragmentation, the moderately preserved planktonic foraminifer assemblages provide the most complete middle Miocene to late Pliocene record in this area. Core 124-771A-1R was placed in late Pliocene Zone N21 which fits well with the age determined from calcareous nannofossils 


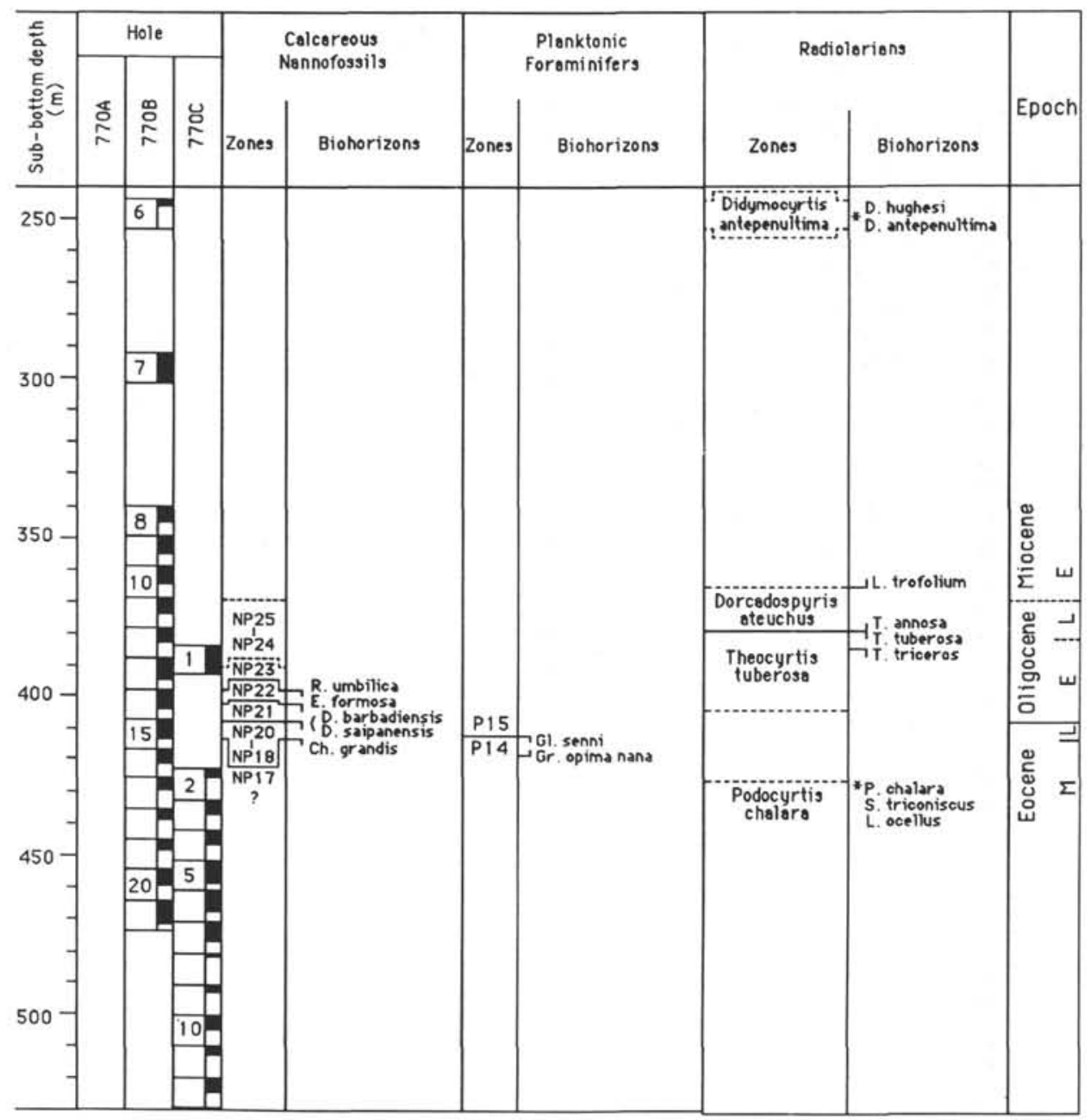

Figure 4 (continued).

(Zones NN15 and NN16). Below that, all boundaries of Zones $\mathrm{N} 17$ to $\mathrm{N} 13$ could be determined. The Globorotalia fohsi lineage is rare in most samples and no attempt was made to divide Zones N12-N10. The base of Zone N10 is marked in Sample 124-771A-9R, CC (222.3 mbsf) by the lowest occurrence of Globorotalia peripheroacuta. The base of Zone N9 is tentatively placed above Sample 124-771A-10R-3, 16-18 cm (225.46 mbsf). A change in preservation was noted near this level. Orbulina spp. are not found in the overlying samples due to dissolution. However, common to abundant Praeorbulina spp. are present below this level while Orbulina spp. are still missing, indicating that the interval below Sample 124$771 \mathrm{~A}-10 \mathrm{R}-3,16-18 \mathrm{~cm}$ should be placed in Zone N8.

An assemblage of pyritized radiolarians of the Diartus petterssoni Zone was found in Core 124-771A-7R (202.9 mbsf). This correlates with an identical assemblage at Site 769. Radiolarians of the late early Miocene Calocycletta costata Zone were found in Cores 124-771A-9R to $-11 \mathrm{R}$ (220-234 mbsf). Preservation, although still poor, is slightly better at Site 771 than at other Sulu Sea sites. Sediments directly overlying pyroclasts are most likely to be still of the Calocycletta costata Zone. If pyroclastic units at all three Sulu Sea sites are similar and are at least partly coeval, then a Calocycletta costata Zone age may be more likely for sediments above (and probably below) pyroclasts at Sites 768 and 769 than the older Stichocorys wolffii Zone age.
Table 4. Biostratigraphic biohorizons/events at Site $\mathbf{7 7 0}$.

\section{CALCAREOUS NANNOFOSSILS:}

BIOHORIZONS*

\begin{tabular}{|c|c|c|}
\hline H.O. & Reticulofenestra umbilica & 398.20 \\
\hline H.O. & Ericsonia formosa & 400.20 \\
\hline H.O. & $\begin{array}{l}\text { Discoaster barbadiensis \& } \\
\text { Discoaster saipanensis }\end{array}$ & 407.95 \\
\hline H.O. & Chiasmolithus grandis & 412.06 \\
\hline
\end{tabular}

PLANKTONIC FORAMINIFERS:

BIOHORIZONS/EVENTS* DEPTH (mbsf)

\begin{tabular}{lll}
\hline H.O. & Globigerina senni & 413.10 \\
L.O. & Globorotalia opima nana & 417.30
\end{tabular}

RADIOLARIANS:

BIOHORIZONS/EVENTS*

DEPTH (mbsf)

\begin{tabular}{lll}
\hline Co-O. & $\begin{array}{l}\text { Diartus hughesi \& Didymocyrtis } \\
\text { antepenultima }\end{array}$ & 250.0 \\
L.O. & Lychnocanoma spp. & 363.6 \\
L.O. & Theocyrtis annosa & 378.6 \\
H.O. & Theocyrtis tuberosa & 378.6 \\
H.O. & $\begin{array}{l}\text { Tristylospyris triceros } \\
\text { Co-O. }\end{array}$ & 384.2 \\
& $\begin{array}{l}\text { Podocyrtis chalara, Sethochytris } \\
\text { triconiscus, \& Lithocyclia ocellus }\end{array}$ & 420.72 \\
\hline
\end{tabular}

${ }^{*}$ L.O. $=$ lowest occurrence, H.O. $=$ highest occurrence, Co-O.= co-occurrence. 


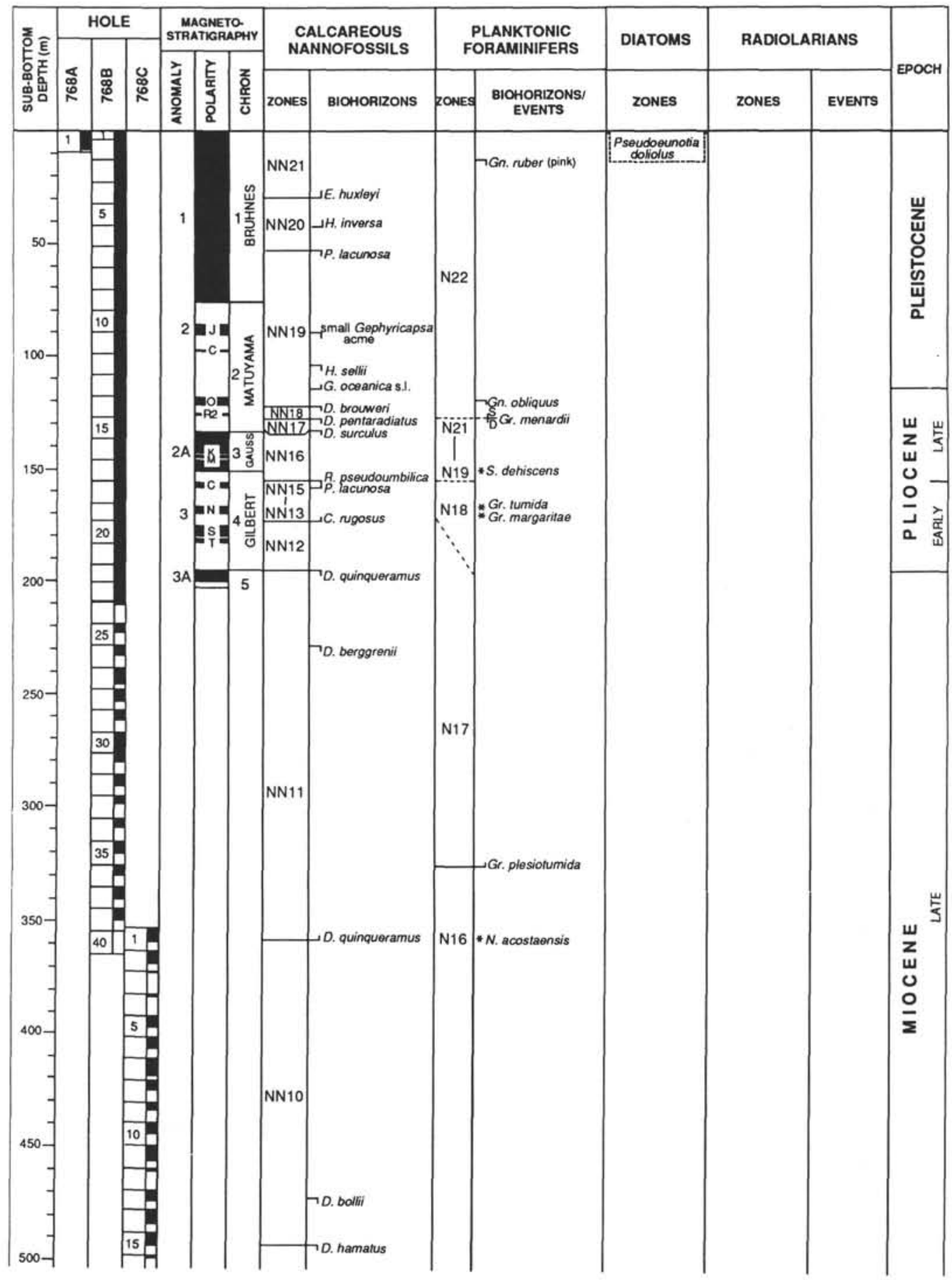

Figure 5. Coring record, magnetostratigraphy, and biostratigraphic zonations at Site 768 . Dotted line in "zones" column indicates uncertain boundary. ${ }^{*}=$ occurrence of marker species, S/D $=$ change in predominant coiling direction.

Diatoms are absent in all Site 771 samples, except some pyritized fragments are found in late middle Miocene sediments. Ichthyoliths are very rare in Site 771 samples. No age-diagnostic forms were found.

\section{DISCUSSION}

The almost complete core recoveries and high-quality paleomagnetic records in the Pliocene and Quaternary sediments at Site 768 and in the late middle Miocene to Quater- nary sediment sequences at Sites 769 provide an opportunity for direct correlation of magnetic reversals and biohorizons. Within all the fossil groups found in the sediments recovered at Site 768 and 769 , calcareous nannofossils have the most consistent occurrences and most biohorizons identified. Other fossil assemblages found in the sediments at both sites provide only approximate ages, and only a few of them can be used to identify biohorizons. The depth of magnetic reversals at each site are listed in Tables 5 and 6 . The age assignments of 


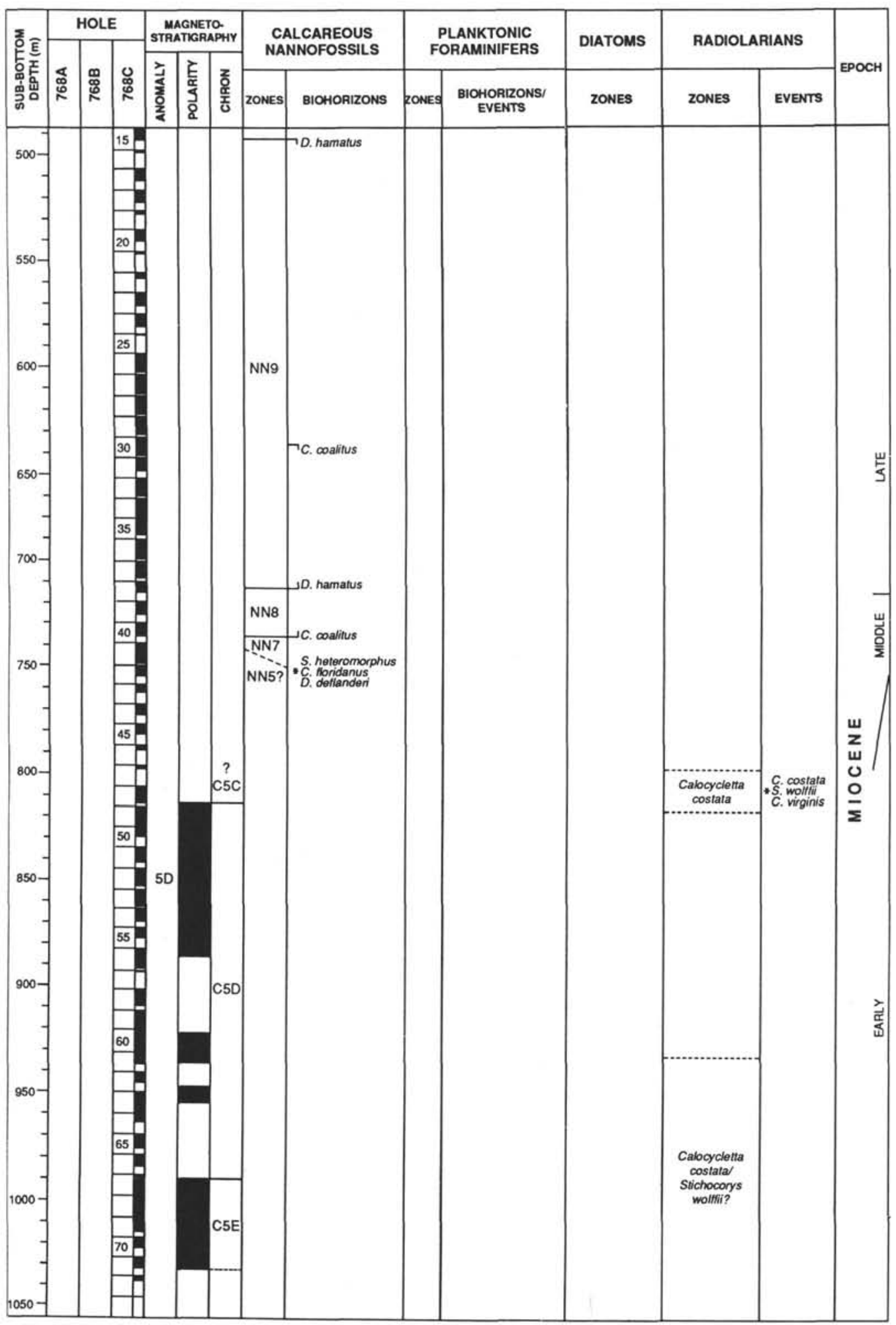

Figure 5 (continued).

reversals follows mainly Berggren et al. (1985b, c; Table 2). The late middle Miocene to Quaternary chronostratigraphic frameworks of Sites 768 and 769 are constructed by plotting the depths of magnetic reversals vs. their assigned ages (Figs. 8 and 9). The ages of biohorizons are then interpolated from the age-depth plots under the assumption that accumulation rates between magnetic reversals are uniform.
The interpolated ages of various biohorizons differ between holes and sites to various degrees and also differ from the reference ages in most cases. Only a few of them are very close or identical to the reference age (Table 8). Redeposition is a very common feature at both sites and can be easily recognized either in the fossil records or in the sediment. Consequently, biohorizons may not be very reliable even if 
Table 5. Magnetic reversal datums and biostratigraphic biohorizons/ events at Site 768 .

\begin{tabular}{|c|c|c|c|}
\hline \multicolumn{4}{|c|}{ CALCAREOUS NANNOFOSSILS: } \\
\hline & BIOHORIZONS* & $768 B$ & $768 \mathrm{C}$ \\
\hline L.O. & Emiliania huxleyi & 29.23 & \\
\hline L.O. & Helicosphaera inversa & 42.55 & \\
\hline H.O. & Pseudoemiliania lacunosa & 53.28 & \\
\hline H.O. & small Gephyrocapsa acme & 89.31 & \\
\hline H.O. & Helicosphaera sellii & 106.85 & \\
\hline L.O. & Gephyrocapsa oceanica s.I. & 114.89 & \\
\hline H.O. & Calcidiscus tropicus & $118.38(?)$ & \\
\hline H.O. & Discoaster brouweri & 122.05 & \\
\hline H.O. & Discoaster pentaradiatus & 128.66 & \\
\hline H.O. & Discoaster surculus & 133.52 & \\
\hline H.O. & Reticulofenestra pseudoumbilica & 155.16 & \\
\hline L.O. & Pseudoemiliania lacunosa & 158.80 & \\
\hline H.O. & Discoaster quinqueramus & 195.01 & \\
\hline H.O. & Discoaster berggrenii & 228.40 & \\
\hline L.O. & Discoaster quinqueramus & & 358.13 \\
\hline H.O. & Discoaster bollii & & 470.95 \\
\hline H.O. & Discoaster hamatus & & 493.16 \\
\hline H.O. & Catinaster coalitus & & 636.16 \\
\hline L.O. & Discoaster hamatus & & 713.66 \\
\hline L.O. & Catinaster coalitus & & 735.50 \\
\hline
\end{tabular}

PLANKTONIC FORAMINIFERS:

$\begin{array}{lcc} & \text { BIOHORIZONS/EVENTS* } & \text { DEPTH (mbsf) } \\ 768 \mathrm{~B}\end{array}$

RADIOLARIANS:

\begin{tabular}{|c|c|c|}
\hline . & HORIZONS/EVENTS* & $\begin{array}{c}\text { DEPTH (mbsf) } \\
768 \mathrm{C}\end{array}$ \\
\hline $\mathrm{C} 0-\mathrm{O}$. & $\begin{array}{l}\text { Calocycletta costata, } \\
\text { Stichocorys wolffi, \& } \\
\text { Calocycletta virginis }\end{array}$ & 806 \\
\hline
\end{tabular}

MAGNETIC REVERSALS:

\begin{tabular}{lc}
\multicolumn{1}{c}{ REVERSALS } & DEPTH (mbsf) \\
\hline BRUNHES/MATUYAMA & $768 \mathrm{~B}$ \\
Top Jaramillo & 76.3 \\
Bottom Jaramillo & 86.1 \\
Top Cobb Mountain & 90.6 \\
Bottom Cobb Mountain & 97.5 \\
Top Olduvai & 98.1 \\
Bottom Olduvai & 118.5 \\
Top Reunion2 & 122.2 \\
Bottom Reunion2 & 125.6 \\
MATUYAMA/GAUSS & 126.0 \\
Top Kaena & 134.4 \\
Bottom Kaena & 142.9 \\
Top Mammoth & 144.4 \\
Bottom Mammoth & 144.9 \\
GAUSS/GILBERT & 146.4 \\
Top Cochiti & 151.0 \\
Bottom Cochiti & 160.9 \\
Top Nunivak & 163.7 \\
Bottom Nunivak & 167.2 \\
Top Sidufjall & 17.0 \\
Bottom Sidufjall & 175.7 \\
Top Thvera & 180.0 \\
Bottom Thvera & 18.0 \\
GILBERT/CHRON 5 & 183.0 \\
Top R-Subchron & 195.0 \\
bottom R-Subchron & 200.0 \\
\hline
\end{tabular}

"L.O.= lowest occurrence, H.O. = highest occurrence, $\mathrm{O}=$ occurrence, $\mathrm{S} / \mathrm{D}=$ change coiling direction. they are in the right order of succession, and the assumption of uniform accumulation rate between magnetostratigraphic control points probably is not warranted. Dissolution is an important factor controlling the preservation of fossils. Signs of dissolution are common in pre-Pleistocene sediments in this area, which increase the difficulties in identifying biohorizons. The poor quality of paleontological data recorded at both sites prohibit further evaluation of numerical age assignments and synchrony of biohorizons.

\section{ACKNOWLEDGMENTS}

We thank Stefan Gartner, William A. Berggren, and J. Butterlin for their critical review of this manuscript. Biostratigraphic and paleomagnetic studies of Leg 124 were supported by National Science Foundation, U.S. Science Program, Deutsche Forschungsgemeinschaft, and Dutch Council for Seagoing Research.

\section{REFERENCES}

Baldauf, J. G., Thomas, E., Clement, B., Takayama, T., Weaver, P.P.E., Backman, J., Jenkins, G., Mudie, P. J., and WestbergSmith, M. J., 1987. Magnetostratigraphic and Biostratigraphic synthesis, Deep Sea Drilling Project Leg 94. In Ruddiman, F., Kidd, R. B., et al., Init. Repts. DSDP, 94 (Pt. 2): Washington (U.S. Govt. Printing Office), 1159-1206.

Barron, J. A., 1985a. Miocene to Holocene planktic diatoms. In Bolli, H. M., Saunders, J. B., and Perch-Nielsen, K (Eds.) Plankton Stratigraphy: Cambridge (Cambridge University Press), 763-810.

Barron, J. A., 1985b. Late Eocene to Holocene diatom biostratigraphy of the equatorial Pacific Ocean, Deep Sea Drilling Project Leg 85. In Mayer, L., Theyer, F., et al., Init. Repts. DSDP, 85: Washington (U.S. Govt. Printing Office), 413-456.

Barron, J. A., Nigrini, C. A., Pujos, A., Saito, T., Theyer, F., Thomas, E., and Weinreich, N., 1985. Synthesis of biostratigraphy, central equatorial Pacific, Deep Sea Drilling Project Leg 85: refinement of Oligocene to Quaternary biochronology. In Mayer, L., Theyer, F., et al., Init. Repts. DSDP, 85: Washington (U.S. Govt. Printing Office), 905-934.

Berggren, W. A., Kent, D. V., and Flynn, J. J., 1985a. Jurassic to Paleogene: Part 2. Paleogene geochronology and chronostratigraphy. In Snelling, N. J. (Ed.), The Chronology of the Geological Record. Geol. Soc. London Mem., 10:141-195.

Berggren, W. A., Kent, D. V., Flynn, J. J., and van Couvering, J. A., 1985b. Cenozoic geochronology. Geol. Soc. Am. Bull., 96: 14071418.

Berggren, W. A., Kent, D. V., and van Couvering, J. A., 1985c. The Neogene: Part 2. Neogene geochronology and chronostratigraphy. In Snelling, N. J. (Ed.), The Chronology of the Geological Record. Geol. Soc. London, Mem., 10:211-260.

Blow, W. H., 1969. Late middle Eocene to Recent planktonic foraminiferal biostratigraphy. In Bronnimann, P. and Renz, H. H. (Eds.), Proc. Ist Int. Conf. Planktonic Microfossils, Geneva, 1967,1: 199-422.

Bolli, H. M., and Saunders, J. B., 1985. Oligocene to Holocene low latitude planktic foraminifera. In Bolli, H. M., Saunders, J. B., and Perch-Nielsen, K. (Eds.), Plankton Stratigraphy: Cambridge (Cambridge University Press), 155-262.

Doyle, P. S., and Riedel, W. R., 1985. Cenozoic and late Cretaceous ichthyoliths. In Bolli, H. M., Saunders, J. B., and Perch-Nielsen, K. (Eds.), Plankton Stratigraphy: Cambridge (Cambridge University Press), 965-995.

Gartner, S., 1990. Neogene calcareous nannofossil biostratigraphy, Leg 116 (central Indian Ocean). InCochran, J. R., Stow, D.A.V., et al., Proc. ODP, Sci. Results, 116: College Station, TX (Ocean Drilling Program), 165-188.

Harland, W. B., Cox, A. V., Liewellyn, P. G., Pickton, C. A. G., and Walters, R., 1982. A Geological Time Scale. Cambridge University Press.

Kennett, J. P., and Srinivasan, M. S., 1983. Neogene Planktonic Foraminifera: A Phylogenetic Atlas. Stroudsburg, Penn. (Hutchinson Ross Publ. Co.). 
Martini, E., 1971. Standard Tertiary and Quaternary calcareous nannoplankton zonation. Proc. 2nd Plankton. Conf., Roma 1970, 2:739-785.

Martini, E. and Müller, C., 1986. Current Tertiary and Quaternary calcareous nannoplankton stratigraphy and correlations. Newsl. Stratigr., 16:99-112.

Rangin, C., Silver, E., von Breymann, M. T., et al., 1990. Proc. ODP, Init. Repts., 124: College Station, TX (Ocean Drilling Program).

Rio, D., Backman, J., and Raffi, I., in press. Calcareous nannofossil biochronology and the Pliocene/Pleistocene boundary. In van Couvering, J. (Ed.), Final Repts., IGCP Project 41.

Sanfilippo, A., Westberg-Smith, M. J., and Riedel W.R., 1985. Cenozoic radiolaria. In Bolli, H. M., Saunders, J. B., and PerchNielsen, K (Eds.), Plankton Stratigraphy: Cambridge (Cambridge University Press), 63I-713.

Stainforth, R. M., Lamb, J. L., Luterbacher, H. p., Beard, J. H., and Jeffords, R. M., 1975. Cenozoic planktonic foraminiferal zonation and characteristics of index forms. Univ. Kansas Paleontol. Contr., 62:1-425.
Takayama, T. and Sato, T., 1987. Coccolith biostratigraphy of the North Atlantic Ocean, Deep Sea Drilling Project Leg 94. In Ruddiman, F., Kidd, R. B., et al., Init. Repts. DSDP, 94: Washington (U.S. Govt. Printing Office), 651-702.

Thompson, P. R., Be, A.W.H., Duplessy, J.-C., and Shackleton, N. J., 1979. Disappearance of pink-pigmented Globigerinoides ruber at $120,000 \mathrm{yr}$ BP in the Indian and Pacific Oceans. Nature, 280:554-558.

Toumarkine, M., and Luterbacher, H., 1985. Paleocene and Eocene planktonic foraminifera. In Bolli, H. M., Saunders, J. B., and Perch-Nielsen, K. (Eds.) Plankton Stratigraphy: Cambridge (Cambridge University Press), 87-154.

Date of initial receipt: 28 September 1990

Date of acceptance: 25 March 1991

Ms 124B-171

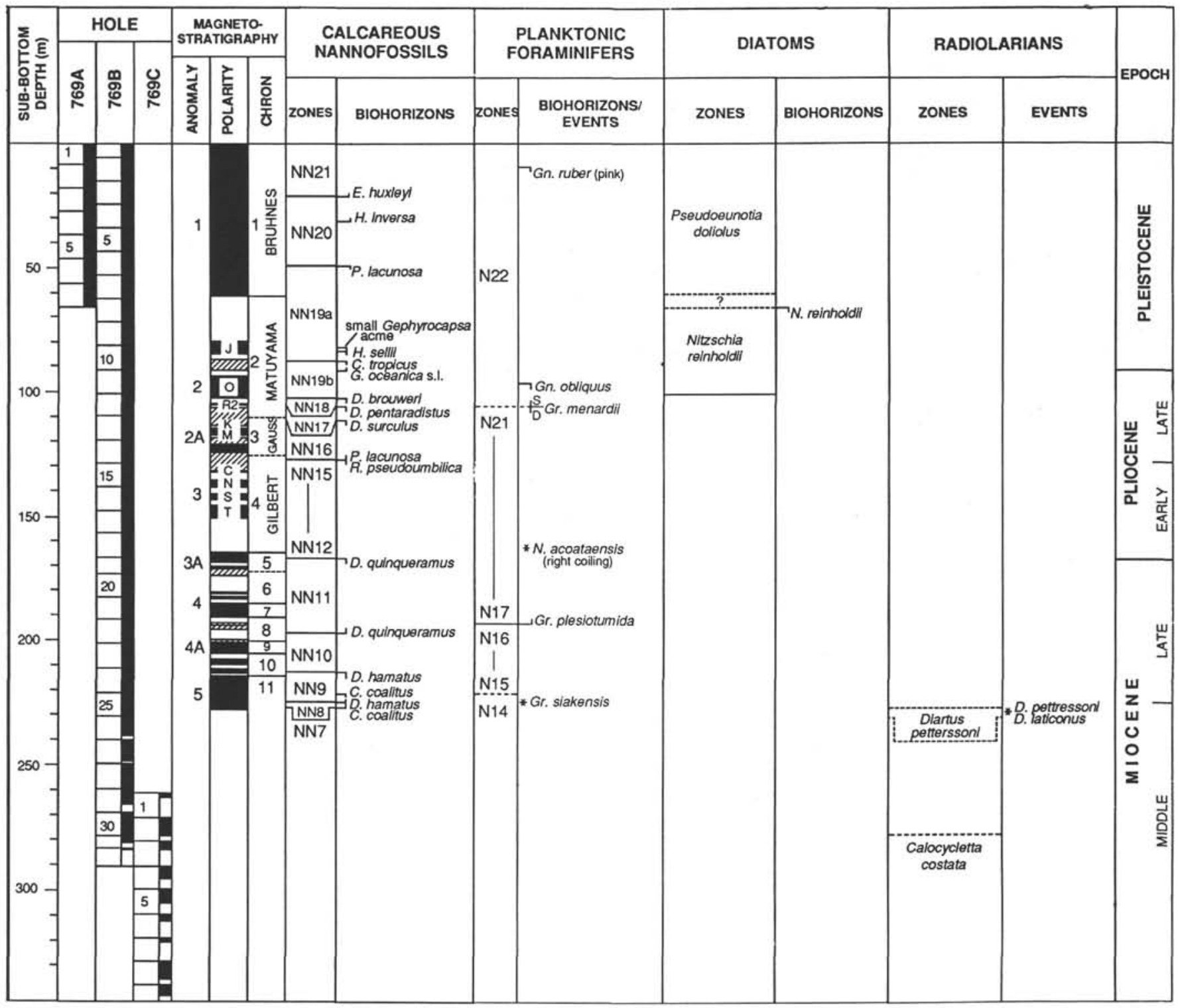

Figure 6. Coring record, magnetostratigraphy and biostratigraphic zonations at Site 769. Shaded interval in "polarity" column means unidentified section. Dotted line in "zones" column indicates uncertain boundary. ${ }^{*}=$ occurrence of marker species, $\mathrm{S} / \mathrm{D}=$ change in predominant coiling direction. 
Table 6. Magnetic reversal datums and biostratigraphic biohorizons/ events at Site 769.

\section{CALCAREOUS NANNOFOSSILS:}

\begin{tabular}{lllr} 
& & \multicolumn{2}{c}{ DEPTH (mbsf) } \\
& BIOHORIZONS* & $769 \mathrm{~A}$ & $769 \mathrm{~B}$ \\
\hline L.O. & Emiliania huxleyi & 21.65 & 21.30 \\
L.O. & Helicosphaera inversa & 24.65 & 30.80 \\
H.O. & Pseudoemilioania lacunosa & 37.65 & 49.70 \\
H.O. & small Gephrocapsa acme & & 82.20 \\
H.O. & Helicosphaera sellii & & 86.20 \\
H.O. & Calcidiscus tropicus & & 88.20 \\
L.O. & Gephyrocapsa oceanica s.l. & & 91.60 \\
H.O. & Discoaster brouweri & & 102.20 \\
H.O. & Discoaster pentaradiatus & & 105.28 \\
H.O. & Discoaster surculus & & 110.90 \\
H.O. & Reticulofenestra pseudoumbilica & & 127.70 \\
L.O. & Peudoemiliania lacunosa & & 127.70 \\
H.O. & Discoaster quinqueramus & & 167.20 \\
L.O. & Discoaster quinqueramus & & 196.42 \\
H.O. & Discoaster hamatus & 213.12 \\
L.O. & Discoaster hamatus & & 224.42 \\
L.O. & Catinaster coalitus & & 226.27 \\
& & &
\end{tabular}

PLANKTONIC FORAMINIFERS:

BIOHORIZONS/EVENTS*

\begin{tabular}{llr}
\hline H.O. & Globigerinoides ruber (pink) & 9.05 \\
H.O. & Globigerinoides obliquus & 95.99 \\
S/D & Globorotalia menardii & 105.69 \\
L.O. & Globorotalia plesiotumida & 192.30 \\
O. & Globorotalia siakensis & 226.24
\end{tabular}

DIATOMS:

\begin{tabular}{cccc} 
& \multirow{2}{*}{ BIOHORIZONS* } & \multicolumn{2}{c}{ DEPTH (mbsf) } \\
& & $769 \mathrm{~A}^{*}$ & $769 \mathrm{~B}$ \\
\hline H.O. & Nitzschia reinholdii & 65.4 & 62.4
\end{tabular}

\section{RADIOLARIANS:}

\begin{tabular}{ccc} 
& BIOHORIZONS /EVENTS* & DEPTH (mbsf) \\
\hline Co-O. & $\begin{array}{l}\text { Diartus petterssoni \& } \\
\text { Didymocyrtis laticonis }\end{array}$ & 230.3
\end{tabular}

Table 6 (continued).

\begin{tabular}{|c|c|c|}
\hline \multirow{2}{*}{$\begin{array}{c}\text { MAGNETIC REVERSALS: } \\
\text { REVERSALS }\end{array}$} & \multicolumn{2}{|c|}{ DEPTH (mbsf) } \\
\hline & $769 A^{D}$ & 769B \\
\hline BRUNHES/MATUYAMA & 62.4 & 61.8 \\
\hline Top Jaramillo & & 79.5 \\
\hline Bottom Jaramillo & & 84.5 \\
\hline Top Olduvai & & 93.6 \\
\hline Bottom Olduvai & & 102.3 \\
\hline Top Reunion2 & & 104.3 \\
\hline Bottom Reunion2 & & 104.7 \\
\hline MATUYAMA/GAUSS & & - \\
\hline Top Kaena & & - \\
\hline Bottom Kaena & & 114.5 \\
\hline Top Mammoth & & 117.0 \\
\hline Bottom Mammoth & & - \\
\hline GAUSS/GILBERT & & - \\
\hline Top Cochiti & & - \\
\hline Bottom Cochiti & & 132.6 \\
\hline Top Nunivak & & 135.2 \\
\hline Bottom Nunivak & & 138.3 \\
\hline Top Sidufjall & & 141.6 \\
\hline Bottom Sidufjall & & 143.4 \\
\hline Top Thvera & & 145.5 \\
\hline Bottom Thvera & & 150.3 \\
\hline GILBERT/CHRON 5 & & 164.2 \\
\hline Top R-Subchron & & 168.5 \\
\hline Bottom R-Subchron & & 170.1 \\
\hline CHRON 5/CHRON 6 & & $171.2-174.0$ \\
\hline Top N-Subchron & & 180.6 \\
\hline Bottom N-Subchron & & 181.5 \\
\hline Top N-Subchron & & 182.1 \\
\hline Bottom N-Subchron & & 183.8 \\
\hline CHRON 6/CHRON 7 & & 184.8 \\
\hline CHRON 7/CHRON 8 & & 191.5 \\
\hline Top N-Subchron & & $193.2-193.5$ \\
\hline \multicolumn{3}{|l|}{ MAGNETIC REVERSALS: } \\
\hline & \multicolumn{2}{|c|}{ DEPTH (mbsf) } \\
\hline REVERSALS & $769 \mathrm{~A}$ & $769 \mathrm{~B}$ \\
\hline Bottom N-Subchron & & $193.7-195.3$ \\
\hline CHRON 8/CHRON 9 & & $199.4-200.1$ \\
\hline CHRON 9/CHRON 10 & & 204.9 \\
\hline Top N-Subchron & & 207.2 \\
\hline Bottom N-Subchron & & 209.2 \\
\hline Top N-Subchron & & 211.3 \\
\hline Bottom N-Subchron & & 212.8 \\
\hline CHRON 10/CHRON11 & & 213.5 \\
\hline
\end{tabular}

${ }^{*} \mathrm{~L} . \mathrm{O} .=$ lowest occurrence, $\mathrm{H} . \mathrm{O} .=$ highest occurrence, $\mathrm{Co}-\mathrm{O} .=$ co-occurrence, $\mathrm{O} .=$ occurrence, $\mathrm{S} / \mathrm{D}=$ change coiling direction. 
BIOSTRATIGRAPHIC AND MAGNETOSTRATIGRAPHIC SYNTHESIS

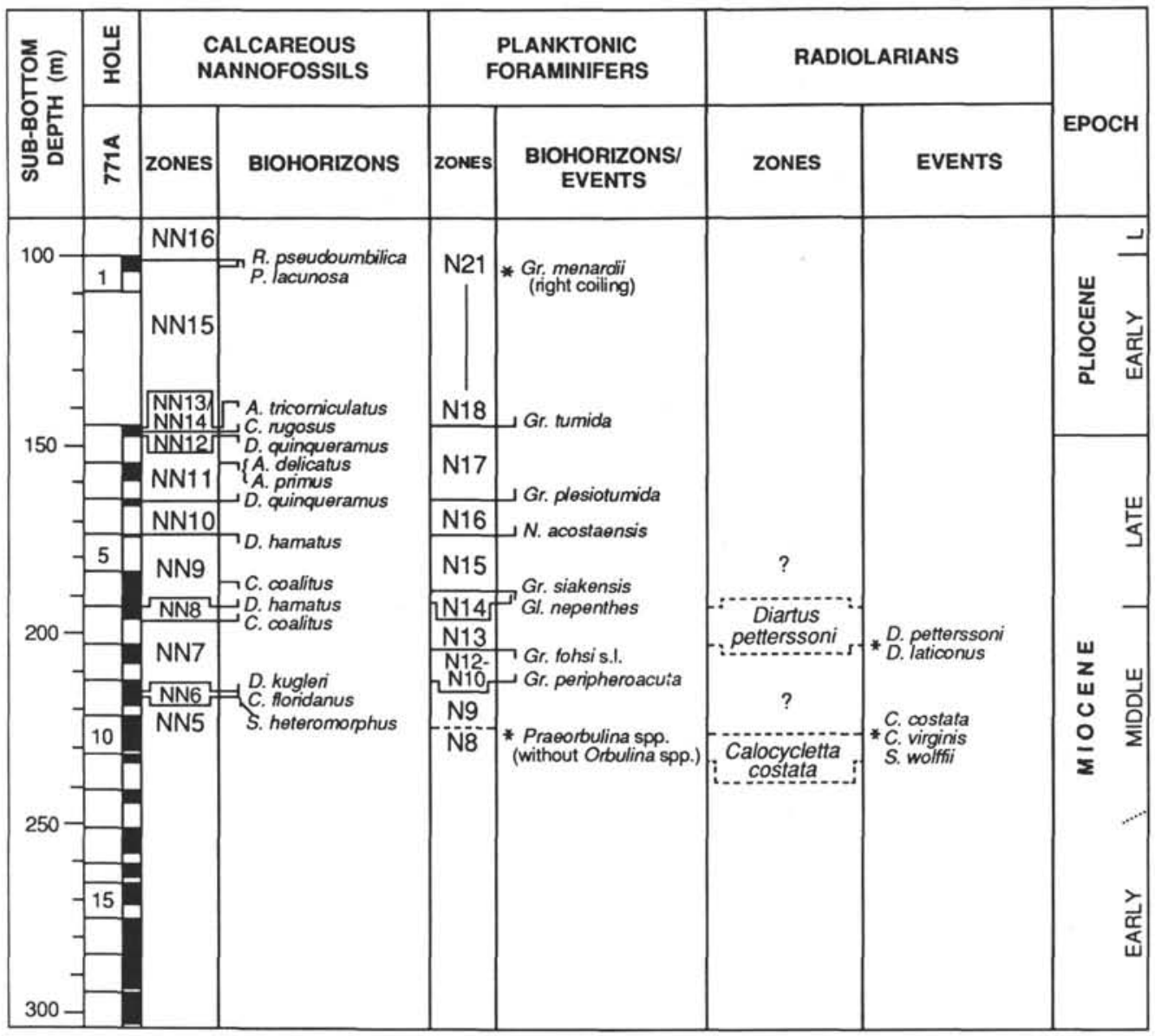

Figure 7. Coring record and biostratigraphic zonations at Site 771. Dotted line in "zones" column indicates uncertain boundary. ${ }^{*}=$ occurrence of marker species. 
Table 7. Biostratigraphic biohorizons/events at Site 771.

CALCAREOUS NANNOFOSSILS:

BIOHORIZONS* DEPTH (mbsf)

\begin{tabular}{|c|c|c|}
\hline H.O. & Reticulofenestra pseudoumbilica & 101.79 \\
\hline L.O. & Pseudoemiliania lacunosa & 102.70 \\
\hline H.O. & Amauroilthus tricorniculatus & 144.88 \\
\hline L.O. & Ceratolithus rugosus & 145.97 \\
\hline H.O. & Discoaster quinqueramus & 146.09 \\
\hline H.O. & Discoaster berggrenii & 146.09 \\
\hline L.O. & Discoaster quinqueramus & 164.45 \\
\hline H.O. & Discoaster bollii & 164.95 \\
\hline H.O. & Discoaster hamatus & 173.97 \\
\hline H.O. & Catinaster coalitus & 186.85 \\
\hline L.O. & Discoaster hamatus & 192.72 \\
\hline L.O. & Catinaster coalitus & 194.95 \\
\hline L.O. & Discoaster kugleri & 214.35 \\
\hline H.O. & Cyclicargolithus floridanus & 214.35 \\
\hline H.O. & Sphenolithus heteromorphus & 216.35 \\
\hline \multicolumn{3}{|c|}{ PLANKTONIC FORAMINIFERS: } \\
\hline \multicolumn{2}{|c|}{ BIOHORIZONS/EVENTS* } & DEPTH (mbsf) \\
\hline o. & right coiling Globorotalia menardii & $100.0-109.6$ \\
\hline L.O. & Globorotalia tumida & 144.86 \\
\hline L.O. & Globorotalia plesiotumida & 164.20 \\
\hline L.O. & Neogloboquarina acostaensis & 173.90 \\
\hline H.O. & Globorotalia siakensis & 188.69 \\
\hline L.O. & Globigerina nepenthes & 191.65 \\
\hline H.O. & Globorotalia fohsi s.l. & 207.60 \\
\hline L.O. & Globorotalia peripheroacuta & 222.30 \\
\hline o. & $\begin{array}{l}\text { Praeorbulina spp. without Orbulina } \\
\text { spp. }\end{array}$ & $225.46-232.0$ \\
\hline \multicolumn{3}{|c|}{ RADIOLARIANS: } \\
\hline \multicolumn{2}{|c|}{ BIOHORIZONS/EVENTS* } & DEPTH (mbsf) \\
\hline Co-O. & $\begin{array}{l}\text { Didymocyrtis petterssoni \& } \\
\text { Didymocyrtis laticonus }\end{array}$ & 202.9 \\
\hline Co-O. & $\begin{array}{l}\text { Calocycletta costata, Calocycletta } \\
\text { virginis, \& Stichocorys wolffii }\end{array}$ & $220-234$ \\
\hline
\end{tabular}

${ }^{*}$ L.O. $=$ lowest occurrence, H.O. $=$ highest occurrence, $\mathrm{Co}-\mathrm{O} .=$ co-occurrence. 


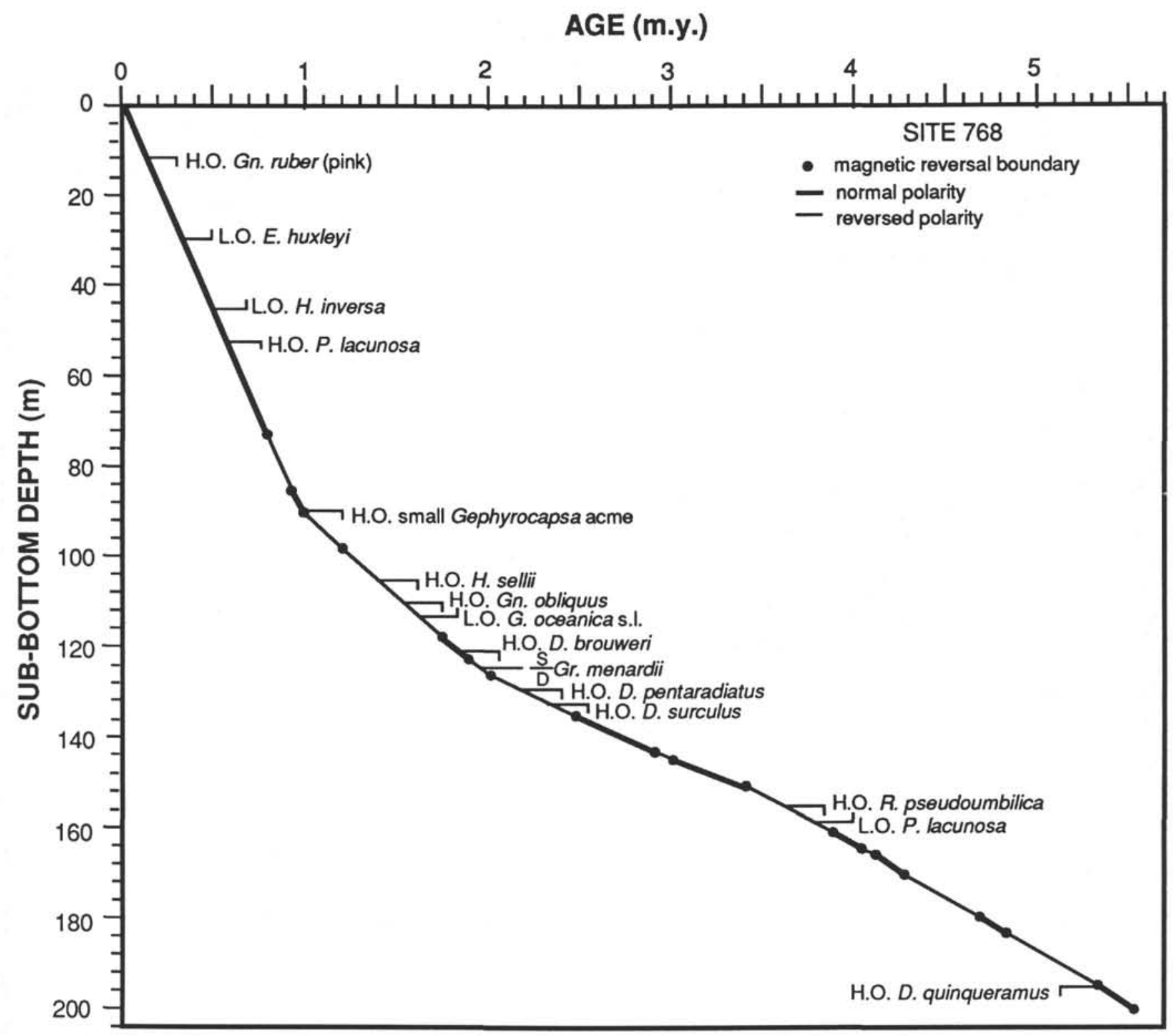

Figure 8. Age vs. depth plot of Pliocene to Quaternary magnetic reversals and biohorizons at Site 768 . All data from Tables 2 amd 5. Interpolated ages of biohorizons are listed in Table 8. H.O. = highest occurrence, L.O. = lowest occurrence. 


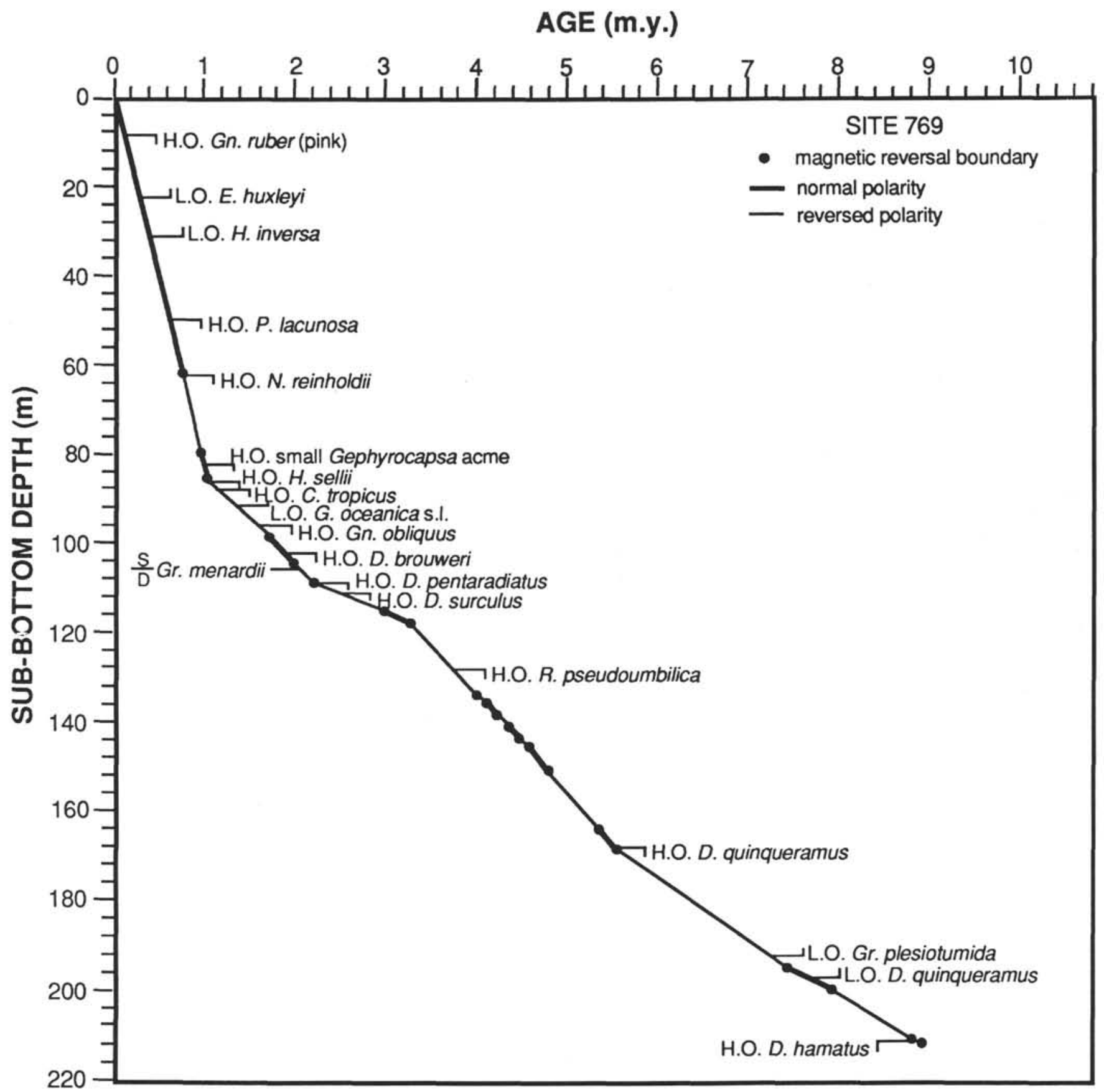

Figure 9. Age vs. depth plot of late middle Miocene to Quaternary magnetic reversals and biohorizons at Site 769. All data from Tables 2 and 6. Interpolated ages of biohorizons are listed in Table 8. H.O. = highest occurrence, L.O.= lowest occurrence. 
Table 8. Ages of biohorizons extrapolated from magnetic reversals at Sites 768 and 769.

\begin{tabular}{|c|c|c|c|c|c|}
\hline \multicolumn{2}{|c|}{ CALCAREOUS NANNOFOSSILS: } & \multicolumn{3}{|c|}{ Interpolated Age (m.y.) } & \multirow{2}{*}{$\begin{array}{l}\text { Reference }{ }^{1} \\
\text { Age (m.y.) }\end{array}$} \\
\hline & BIOHORIZONS & $768 \mathrm{~B}$ & $769 \mathrm{~A}$ & $769 \mathrm{~B}$ & \\
\hline L.O. & Emiliania huxleyi & 0.279 & 0.253 & 0.251 & 0.275 \\
\hline L.O. & Helicosphaera inversa & 0.409 & 0.288 & 0.363 & \\
\hline H.O. & Pseudoemiliania lacunosa & 0.51 & 0.59 & 0.58 & 0.474 \\
\hline H.O. & small Gephyrocapsaacme & 0.96 & 0.95 & 0.93 & 0.93 \\
\hline H.O. & Helicosphaera sellii & 1.35 & & 1.11 & 1.37 \\
\hline H.O. & Calcidiscus tropicus & $1.65(?)$ & & 1.26 & 1.48 \\
\hline L.O. & Gephyrocapsa oceanica s.I. & 1.56 & & 1.51 & 1.59 \\
\hline H.O. & Discoaster brouweri & 1.87 & & 1.88 & 1.89 \\
\hline H.O. & Discoaster pentaradiatus & 2.17 & & 2.10 & 2.29 \\
\hline H.O. & Discoaster surculus & 2.42 & & 2.64 & 2.42 \\
\hline H.O. & Reticulofenestra pseudoumbilica & 3.60 & & 3.69 & 3.51 \\
\hline L.O. & Pseudoemiliania lacunosa & 3.78 & & 3.69 & 4.0 \\
\hline H.O. & Discoaster quinqueramus & 5.35 & & 5.48 & 5.6 \\
\hline L.O. & Discoaster quinqueramus & & & 7.59 & 8.2 \\
\hline H.O. & Discoaster hamatus & & & 8.85 & 8.85 \\
\hline
\end{tabular}

PLANKTONIC FORAMINIFERS:

\begin{tabular}{|c|c|c|c|c|}
\hline \multicolumn{2}{|r|}{ (a) } & \multicolumn{2}{|c|}{ Interpolated Age (m.y.) } & \multirow{2}{*}{$\begin{array}{l}\text { Reference }^{2} \\
\text { Age (m.y.) }\end{array}$} \\
\hline & PHORIZONS & $768 \mathrm{~B}$ & $769 \mathrm{~B}$ & \\
\hline H.O. & $\begin{array}{l}\text { Globigerinoides } \\
\text { ruber(pink) }\end{array}$ & 0.11 & 0.13 & 0.12 \\
\hline H.O. & $\begin{array}{l}\text { Globigerinoides } \\
\text { obliquus }\end{array}$ & 1.46 & 1.72 & 1.8 \\
\hline S/D & Globorotalia menardii & 2.22 & 2.14 & \\
\hline L.O. & $\begin{array}{l}\text { Globorotalia } \\
\text { plesiotumida }\end{array}$ & & 7.2 & 7.4 \\
\hline
\end{tabular}

RADIOLARIANS:

\begin{tabular}{lccc}
\multicolumn{2}{c}{$\begin{array}{c}\text { RADIOLARIANS: } \\
\text { BIOHORIZONS }\end{array}$} & $\begin{array}{c}\text { Interpolated Age (m.y.) } \\
768 \mathrm{C}\end{array}$ & $\begin{array}{c}\text { Reference } \\
\text { Age (m.y.) }\end{array}$ \\
\hline $\begin{array}{l}\text { H.O. } \\
\text { DIATOMS: }\end{array}$ & 17.5 & 17.3 \\
BIOHORIZONS & $\begin{array}{c}\text { Interpolated Age (m.y.) } \\
769 \mathrm{~B}\end{array}$ & $\begin{array}{c}\text { Reference } \\
\text { Age (m.y.) }\end{array}$ \\
\hline H.O. & Nitzschia reinholdii & 0.73 & 0.65 \\
\hline
\end{tabular}

1 See Figure 2.

${ }^{2}$ From Berggren et al. (1985C).

${ }^{3}$ From Sanfilippo et al. (1985), Barron et al. (1985).

${ }^{4}$ From Barron et al. (1985). 